\title{
RESEARCH
}

\section{OXTR overexpression leads to abnormal mammary gland development in mice}

\author{
Dan Li', Yan Ji², Chunlan Zhao', Yapeng Yao', Anlan Yang', Honghong Jin', Yang Chen', Mingjun San', Jing Zhang', \\ Mingjiao Zhang1, Luqing Zhang1,3, Xuechao Feng1,3 and Yaowu Zheng1,3
}

${ }^{1}$ Transgenic Research Center, Northeast Normal University, Changchun, Jilin, China

2Department of Cancer Biology, University of Texas MD Anderson Cancer Center, Houston, Texas, USA

${ }^{3}$ Key Laboratory of Molecular Epigenetics of Ministry of Education, Northeast Normal University, Changchun, Jilin, China

Correspondence should be addressed to Y Zheng: zhengyw442@nenu.edu.cn

\section{Abstract}

Oxytocin receptor (OXTR) is a G-protein-coupled receptor and known for regulation of maternal and social behaviors. Null mutation (Oxtr-l-) leads to defects in lactation due to impaired milk ejection and maternal nurturing. Overexpression of OXTR has never been studied. To define the functions of OXTR overexpression, a transgenic mouse model that overexpresses mouse Oxtr under $\beta$-actin promoter was developed $\left({ }^{++} \mathrm{Oxtr}\right) .{ }^{++} \mathrm{Oxtr}$ mice displayed advanced development and maturation of mammary gland, including ductal distention, enhanced secretory differentiation and early milk production at non-pregnancy and early pregnancy. However, ${ }^{++}$Oxtr dams failed to produce adequate amount of milk and led to lethality of newborns due to early involution of mammary gland in lactation. Mammary gland transplantation results indicated the abnormal mammary gland development was mainly from hormonal changes in ${ }^{++}$Oxtr mice but not from OXTR overexpression in mammary gland. Elevated OXTR expression increased prolactin-induced phosphorylation and nuclear localization of STAT5 (p-STAT5), and decreased progesterone level, leading to early milk production in non-pregnant and early pregnant females, whereas low prolactin and STAT5 activation in lactation led to insufficient milk production. Progesterone treatment reversed the OXTR-induced accelerated mammary gland development by inhibition of prolactin/p-STAT5 pathway. Prolactin administration rescued lactation deficiency through STAT5 activation.

Progesterone plays a negative role in OXTR-regulated prolactin/p-STAT5 pathways. The study provides evidence that OXTR overexpression induces abnormal mammary gland development through progesterone and prolactin-regulated p-STAT5 pathway.

\author{
Key Words \\ - OXTR \\ - mammary gland \\ development \\ - prolactin \\ p-STAT5 \\ - progesterone \\ - RANKL
}

Journal of Endocrinology (2018) 239, 121-136

\section{Introduction}

Abnormal mammary gland development is associated with many diseases including breast cancers (Cardiff et al. 2000). Mammary gland develops through several stages including embryonic development, puberty, pregnancy, lactation and involution (Macias \& Hinck 2012). Mammary gland development requires hormones including prolactin (PRL), progesterone (P4) and estrogen (E2). PRL controls alveologenesis and lactogenesis of mammary gland through phosphorylation of JAK2/STAT5 axis (Yamaji et al. 2009). PRL binds to prolactin receptor (PRLR) and activates STAT5 through JAK2-regulated phosphorylation. Activated STAT5 (p-STAT5) translocates 
to nucleus and regulates the expression of alveolar epithelial differentiation-associated genes and milk protein genes including whey acidic protein (Wap) and $\beta$-casein (Csn2) (Schmitt-Ney et al. 1991, Gouilleux et al. 1994, Li \& Rosen 1995, Liu et al. 1995, Ali \& Ali 1998, Vonderhaar 1999). P4 is required for mammary epithelium proliferation, ductal side-branching and alveolar morphogenesis during pregnancy (Brisken et al. 1998, Mulac-Jericevic et al. 2003). Receptor activator of NFKB1 ligand (RANKL) mediates mouse mammary epithelium proliferative response to P4 (Asselin-Labat et al. 2010, Beleut et al. 2010, Joshi et al. 2010). Moreover, RANKL is in the downstream of PRL signaling. Response of RANKL to both PRL and P4 may indicate RANKL is at the junction of two hormones (Srivastava et al. 2003, Fernandez-Valdivia et al. 2008). Many studies have demonstrated that local cues, including STAT3, leukemia inhibitory factor (LIF), insulin-like growth factor-binding protein-5 (IGFBP5), matrix metalloproteinase 2 (MMP2) and 3 (MMP3), regulate the phase of involution. Deletion of Stat 3 or Lif in mammary gland results in dramatic delay in involution (Chapman et al. 1999, Kritikou et al. 2003). Overexpression of $I g f b p 5, M m p 2$ and $M m p 3$ in mammary gland causes premature involution (Sympson et al. 1994, Fata et al. 2001, Ning et al. 2007).

Oxytocin receptor (OXTR) is a G-protein-coupled receptor for neurotransmitter oxytocin (Kimura et al. 1992). In response to ligand binding, activated OXTR couples to $G_{\alpha q / 11}$ and $G_{\beta \gamma}$ to stimulate phospholipase C- $\beta$ isoforms, leading to various cellular events and increased intracellular $\left[\mathrm{Ca}^{2+}\right]$. OXTR is known to be expressed in mammary gland (Kimura et al. 1998), uterine myometrium (Helmer et al. 1998), cardiac muscle of heart (Gutkowska et al. 1997), vascular endothelium layer (Thibonnier et al. 1999) and specific brain regions (Insel et al. 1993, Hidema et al. 2016). Many functions of OXTR have been studied using null mutation (Oxtr-I-). Oxtr-/- mice elicit abnormal sexual, social behaviors (Takayanagi et al. 2005), obesity and thermoregulation disorder (Kasahara et al. 2015). Oxtr-/- mice exhibit normal reproduction but defective in lactation. All offspring from Oxtr-/- dams died within $24 \mathrm{~h}$ after birth due to impaired milk ejection and defect in maternal nurturing (Takayanagi et al. 2005, Hidema et al. 2016). However, either deficient or excessive gene expression can lead to pathologic development and disease. Whether overexpression of OXTR has any effect on mammary gland development and how OXTR regulates mammary gland development are still not clear.

To investigate the role of excessive OXTR in mammary gland development, we generated an OXTR overexpression mouse model. OXTR overexpression produced distinct phenotypes including early mammary gland development and involution. The study describes the impact of OXTR on mammary gland development through hormonal changes.

\section{Materials and methods}

\section{Materials and reagents}

All general chemicals were purchased from Sigma and enzymes for molecular cloning were from New England Biolabs, USA and Takara.

\section{Animals}

The entire study was approved by the Animal Experimental Ethics Committee of Northeast Normal University (NENU/IACUC). All mouse work was conducted in accordance with the recommendations in the Guide for Care and Use of Laboratory Animals of National Institutes of Health and UK legal requirements.

C57BL/6J (B6), DBA/2, CD1 mice were purchased from Vital River (A Charles River Company, Beijing, China). All animals were maintained under pathogen-free conditions at $21 \pm 1^{\circ} \mathrm{C}, 50 \pm 20 \%$ relative humidity and 12 :12-h light/ darkness cycle. Mice were housed in IVC cages (5 per cage) with free access to regular chow and water. Females at various stages of mammary gland development were used in the study and WT littermates were used as control. Mice were anesthetized with $1 \%$ pentobarbital natrium at a dose of $10 \mathrm{mg} / \mathrm{kg}$ intraperitoneally before experiments.

\section{Generation of $\beta$-actin-Oxtr (++Oxtr) mice}

\section{Plasmid construction}

Briefly, $1.2 \mathrm{~kb}$ mouse Oxtr coding region was PCRamplified from mouse mammary gland cDNA and inserted after $\beta$-actin promoter of pCAGGS (LMBP2453, Laboratory of Molecular Genetics, Institute of Medical Science, University of Tokyo). A $3.5 \mathrm{~kb}$ fragment including $\beta$-actin promoter, mouse Oxtr cDNA and $\beta$-Globin intron and polyA was excised and purified using Qiagen Gel Extraction Kit (Qiagen). The purified DNA fragment was diluted with injection buffer to a $2 \mathrm{ng} / \mu \mathrm{L}$ concentration.

\section{Zygotes collection, microinjection, and transferring}

Transgenic mice overexpressing mouse oxytocin receptor gene $\left(^{++} \mathrm{Oxtr}\right)$ were generated by pronuclear microinjection. 
Six-week-old and sexually emergent F1 $(\mathrm{B} 6 \times \mathrm{DBA} / 2)$ females were superovulated by intraperitoneal injection of 5 IU PMSG followed by 5 IU hCG at an interval of $46 \mathrm{~h}$. Mating was set with C57BL/6J stud male for overnight. Zygotes were collected from the infundibulum region of oviduct into M2 medium in the morning, digested with hyaluronidase and transferred into M16 medium. DNA solution $(2 \mathrm{ng} / \mu \mathrm{L})$ was pronucleus-injected into C57/BL6J/DBA zygotes using an Olympus IX71 inverted microscope equipped with Narishige microinjector. More than 120 zygotes of two-cell stage were obtained after injection and overnight culture, and then oviducttransferred to pseudo-pregnant CD1 females. The pseudo-pregnant females were prepared by mating with C57BL/6J/DBA males.

\section{Genotyping}

Transgenic founders were identified by PCR. Genomic DNA was extracted from tail tips. In brief, samples were digested with GNTK buffer $\left(50 \mathrm{mM} \mathrm{KCl}, 1 \mathrm{M} \mathrm{MgCl}_{2}\right.$, $10 \mathrm{mM}$ Tris- $\mathrm{HCl}, \mathrm{pH} 8.5,0.01 \%$ gelatin, $0.45 \%$ Nonidet $\mathrm{P}-40,0.45 \%$ Tween 20 and $100 \mathrm{mg} / \mathrm{mL}$ proteinase $\mathrm{K}$ ) at $55^{\circ} \mathrm{C}$ overnight (Malumbres et al. 1997). The lysates were diluted and boiled for $15 \mathrm{~min}$. PCR was performed at $94^{\circ} \mathrm{C}$ for $2 \mathrm{~min}$, followed by 30 cycles of denaturing at $94^{\circ} \mathrm{C}$ for $30 \mathrm{~s}$, annealing at $57^{\circ} \mathrm{C}$ for $30 \mathrm{~s}$ and extension at $72^{\circ} \mathrm{C}$ for $1 \mathrm{~min}$. Final extension was at $72^{\circ} \mathrm{C}$ for $10 \mathrm{~min}$. The PCR primers are located in rb_glob_PA_terminator of pCAGGS vector, pCAGGS Forward (1785-1806): AATGCCCTGGCTCACAAATAC; pCAGGS Reverse (2240-3363): GGGACAGCTATGACTGGGAGTAG. Eight pups were found carrying the transgene (founders). Transgenic mice were switched to C57/BL6J genetic background $(\geq 98 \%)$ by consecutive mating with C57/BL6J mice for more than five generations.

\section{Real-time PCR}

Total RNA was extracted from mouse tissues using TRIzol reagent (Takara). One microgram of total RNA was reversibly transcribed with Prime Script cDNA Synthesis Kit from Takara according to manufacturer's instruction. Real-time PCR was carried out using SYBR Green Mix (Takara) following standard procedures. Quantification was calculated using the $2^{-\triangle \Delta C T}$ value method. All PCR results were normalized to expression level of $18 \mathrm{~S}$ ribosomal RNA. PCR primers were listed in Supplementary Table 1 (see section on supplementary data given at the end of this article).

\section{Histology analysis and immunohistochemistry}

For histological analysis, $5 \mu \mathrm{m}$ sections of $4 \%$ paraformaldehyde (PFA)-fixed, paraffin-embedded mammary glands were stained with hematoxylin and eosin (H\&E) (Marshall \& Horobin 1973). For immunostaining (Ramos-Vara 2005), a 15-min antigen heat retrieval in EDTA ( $\mathrm{pH}$ 8.0) was performed. Primary antibodies: rabbit anti-OXTR (ab181077, Abcam, 1:500) and rabbit anti-Phosoho-STAT5 (9359s, Cell Signaling Technology (CST), 1:600). The slides were incubated with primary antibodies overnight at $4^{\circ} \mathrm{C}$. Secondary antibody was HRPconjugated anti-rabbit IgG (8114P, CST, USA). The slides were incubated with secondary antibodies for $30 \mathrm{~min}$ at room temperature. Peroxidase signal was revealed with DAB (CST, USA). The slides were counterstained with hematoxylin, and positively stained cells appeared brown.

\section{Mammary gland whole mount}

One of the 4rd inguinal mammary glands was dissected and spread on a glass slide. After fixation with Carnoy solution (ethanol, chloroform, glacial acetic acid; 6:3:1), gland was rehydrated gradually through a series of diluted ethanol and immersed in carmine aluminum solution (1 $\mathrm{g}$ carmine and $2.5 \mathrm{~g}$ aluminum potassium sulfate were dissolved into $500 \mathrm{~mL}$ distilled water by boiling for 20 min) (Plante et al. 2011) for staining overnight at room temperature. Dehydrated gland through serial ethanol baths (50, 70, 95 and 100\%) was cleared in xylene and examined under an Olympus IX71 inverted microscopy.

\section{Lactation analysis and mammary gland development in lactation}

Neonatal growth and survival, milk yield, mammary gland morphology, major milk protein gene expression and involution-associated gene expression were analyzed to assess changes in lactation (Palmer et al. 2006).

To analyze milk yield and neonatal growth, embryos from B6 were transferred in WT and ${ }^{++}$Oxtr dams to eliminate the effect of pups' genotypes using procedures described 'Zygotes collection, microinjection and transferring' section. Milk yield was accessed using daily litter weight gain of pups. The number of pups nursed by WT dam was the same as that nursed by the ${ }^{++}$Oxtr dam. Pups from each litter were weighed every $24 \mathrm{~h}$, and litter weights and average body weights were recorded. Crossfostering experiments were used to rule out possible pupdependent effects where pups from WT dams were placed 
on ${ }^{++}$Oxtr dams, and pups from ${ }^{++} O x t r$ dams were placed on WT dams.

Whole-mount and histological staining was used to define the progressive changes in mammary gland morphology during lactation. The major milk protein gene expression (Csn2 and Wap) was used to examine mammary gland differentiation.

\section{Mammary gland transplantation}

This procedure is used to assess phenotypes of mammary gland development determined by the effects of genotype in mammary epithelial or a supportive micro-environment. Alveolar and ducts repopulating into mammary fat pad were evaluated. The endogenous mammary epithelium was removed from the 4rd inguinal glands of 3-weekold WT or ${ }^{++}$Oxtr virgin females to provide a cleared mammary fat pad (supportive micro-environment). The donor epitheliums were prepared as follows: the 4rd mammary gland of 3-week-old WT or ${ }^{++} O x$ tr virgin females were harvested and minced into $1 \mathrm{~mm}^{3}$ fragments in DMEM/F12. The $1 \mathrm{~mm}^{3}$ fragments of donor epitheliums were inserted into the cleared mammary fat pads. Donor epithelium from WT was inserted to the left side and ${ }^{++}$Oxtr on the right side. Eight weeks after transplantation, fat pads were excised for whole-mount staining (Dunphy et al. 2010).

\section{Hormone treatment}

Progesterone (Sigma, P-7556; Sigma Chemical) and prolactin (BBI Life Sciences, D824BC0272, China) were diluted in sterile saline $(0.9 \% \mathrm{NaCl})$ to the final concentration of $3 \mathrm{mg} / \mathrm{mL}$ and $10 \mathrm{ng} / \mathrm{\mu L}$ respectively. WT and ${ }^{++}$Oxtr virgin females were treated with $300 \mu \mathrm{g}$ progesterone subcutaneously daily for 7 days. ${ }^{++}$Oxtr females at late pregnancy were treated with $300 \mu \mathrm{g}$ progesterone subcutaneously or $50 \mathrm{ng} / \mathrm{g}$ PRL intraperitoneally for three consecutive days (P18.5, P19.5, L1). Control littermates at the same stage were treated in parallel with saline.

\section{ELISA for hormone measurements}

Serum samples were collected at various stages and prepared by clotting for $30 \mathrm{~min}$ and centrifuging at $400 \mathrm{~g}$ room temperature. ELISA assays were performed according to manufacturer's instruction. The optical density was measured using microplate reader (SpectraMax, Molecular Device, USA). ELISA kit for mouse progesterone (Cat DEV9988, DEMEDITEC Diagnostics GmbH, Germany) has the sensitivity of $0.04 \mathrm{ng} / \mathrm{mL}$. The intra-assay and inter-assay variation are $<9.9 \%$ and $<7.6 \%$, respectively. ELISA kit for mouse prolactin (Cat AB100736, Abcam) has the sensitivity of $30 \mathrm{pg} / \mathrm{mL}$. The intra-assay and interassay variation are $<10 \%$ and $<12 \%$, respectively. ELISA kit for mouse Estradiol (Cat ADI-900-174, Enzo, USA) has the sensitivity of $14 \mathrm{pg} / \mathrm{mL}$. The intra-assay and inter-assay variation are $<7.1 \%$ and $14.2 \%$, respectively.

\section{Immunoblotting}

Ovary, uterus and mammary gland protein was extracted in RIPA buffer. $40 \mu \mathrm{g}$ of total protein was separated on 10\% SDS-PAGE and transferred to PVDF membranes (Towbin et al. 1979). The membranes were incubated with primary antibodies overnight $(12 \mathrm{~h})$ at $4^{\circ} \mathrm{C}$. The primary antibodies used were rabbit anti-OXTR (Abcam, ab181077; 1:5000), rabbit anti-Phosoho-STAT5 (CST, USA, 9359s; 1:1000), goat anti-RANKL (R\&D Systems, AF462; 1:2000) and rabbit anti-GAPDH (Bioworld, USA, AP0063, 1: 10,000). Following three washes with TBST, the membranes were incubated with secondary antibodies for $1 \mathrm{~h}$ at room temperature. The secondary antibodies used were horseradish peroxidase (HRP)-conjugated donkey anti-rabbit IgG (GE Healthcare, USA, 1:3000) and HRPconjugated rabbit anti-goat IgG (Bioworld, USA, BS30503, 1: 10,000). Amersham ${ }^{\mathrm{TM}} \mathrm{ECL}^{\mathrm{TM}}$ (GE Healthcare, USA) was used as signal detection (Renart et al. 1979). GAPDH is served as a loading control.

\section{Statistical analysis}

All values reported are presented as means \pm standard error of means (s.E.M.). $P$ value was calculated with one-way ANOVA to compare three or more groups, unpaired twotailed Student's $t$-tests to compare two groups and logrank (Mantel-Cox) test for survival analysis. Statistically significant differences are indicated with asterisks $\left({ }^{*} P<0.05 ;{ }^{* *} P<0.01 ;{ }^{* *} P<0.001\right)$.

\section{Results}

OXTR overexpression and localization in developing mammary gland

To explore the role of OXTR in mammary gland development, Oxtr cDNA was transgenically expressed under $\beta$-actin promoter $\left(^{++} \mathrm{Oxtr}\right)$. OXTR expression was examined in female reproductive system, brain, heart, kidney and white adipose tissue (WAT) (Fig. 1A, B and C). 
Real-time PCR (RT-PCR) (Fig. 1A) and immunoblotting (Fig. 1B) results confirmed $O x$ tr expression was upregulated by 14 -folds in ${ }^{++}$Oxtr mammary gland $(P=0.0008)$, 6.4-folds in ovary ( $P=0.009), 6.6$-folds in uterus $(P=0.008)$, 206-folds in brain $(P=0.0004), 21500$-folds in heart ( $P=0.0003), 235$-folds in kidney $(P=0.0006)$ but not in WAT (Fig. 1C).

We further investigated the expression and localization of OXTR in mammary glands at different developmental stages: non-pregnancy 8 weeks and 12 weeks $(8 \mathrm{~W}, 12 \mathrm{~W})$, pregnancy day 3.5 and 9.5 (P3.5, P9.5) and lactation day 1 , 4 and 18 (L1, L4, L18). RT-PCR results indicated that Oxtr mRNA expression in ${ }^{+}$Oxtr mammary gland was constantly higher than WT $(P<0.001$ for each time point) (Fig. 1D). Immunoblotting and immunohistochemistry (IHC) results displayed that OXTR in WT mammary gland was hardly detectable at non-pregnancy, increased during pregnancy and reached a peak in lactation. Compared to $\mathrm{WT},{ }^{++} \mathrm{Oxtr}$ OXTR expression was higher at non-pregnancy $(P=0.0005$ for $8 \mathrm{~W}, P=0.0004$ for $12 \mathrm{~W})$ and early pregnancy $(P=0.006$ for P3.5, $P=0.002$ for P9.5), but lower in lactation ( $P=0.016$ for L1, $P=0.0001$ for L18) (Fig. 1E and F). IHC results indicated that OXTR was localized in developing alveolar and ductal epithelial cells of both WT and ${ }^{++}$Oxtr mammary gland (Fig. 1F). Premature mammary gland development and early involution were clearly demonstrated in ${ }^{++} \mathrm{Oxtr}$ mice (Fig. 1F). Collectively, expression of OXTR in developing mammary gland is altered in ${ }^{+} O x t r$ mice, and $\beta$-actin promoter-driven OXTR overexpression induces abnormal mammary gland development.

OXTR overexpression leads to accelerated mammary gland development and milk production at non-pregnancy and early pregnancy

To examine the impact of OXTR overexpression on mammary gland development, whole-mount staining of mammary glands at different stages was performed. Slight increase in branching of duct and terminal end buds (TEB) numbers was detected in ${ }^{+} O x t r$ mice at 3 and 8 weeks (Fig. 2Aa, b, c, d). ${ }^{++}$Oxtr mice exhibited markedly precocious secretory alveolar differentiation and distension of mammary ducts at 12 weeks (12 W) and pregnancy (P3.5, P9.5) (Fig. 2Ae, f and B). The calibers (diameters) of ${ }^{++}$Oxtr mammary ducts were significantly increased at $12 \mathrm{~W}$ and pregnancy compared to WT $(P<0.0001$ for $12 \mathrm{~W}, \mathrm{P} 3.5$ and P9.5) (Fig. 2C). Hematoxylin and eosin (H\&E) staining results showed accelerated lobuloalveolar development and distended ducts full of proteinaceous material in ${ }^{++} O x t r$ mammary gland (Fig. 2D and Supplementary Fig. 1A). Imaging results of macroscopic mammary morphology revealed presence of liquid milk filled in mammary ducts of nonpregnant and early pregnant ${ }^{++} \mathrm{Oxtr}$ mice (Fig. 2E). Higher mRNA expression of Csn $2(P<0.0001$ for $12 \mathrm{~W}, \mathrm{P} 3.5$ and P9.5) and Wap ( $P<0.0001$ for $12 \mathrm{~W}, \mathrm{P} 3.5$ and P9.5) (two major milk protein genes) in ${ }^{++} O x t r$ mice than WT was in accordance with the morphological changes and precocious secretory differentiation (Fig. 2F). These results demonstrate that OXTR overexpression induces early secretory alveolar maturation at non-pregnancy and early pregnancy.

\section{Early secretory lobuloalveolar involution results in postnatal lactation failure}

All offspring from ${ }^{++}$Oxtr dams died during lactation, regardless of the genotype of offspring $(P<0.001)$ (Fig. 3A). In order to eliminate the effect of pups' genotypes, WT embryos were oviduct transferred to pseudo-pregnant WT and ${ }^{++}$Oxtr females. Milk yield was accessed using daily litter weight gains of pups after embryos transfer (ET) (Fig. 3B). The number of pups nursed by WT dam was the same as that nursed by ${ }^{++}$Oxtr dam. ${ }^{++}$Oxtr dams had a significantly lower milk yield than WT dams during lactation $(P<0.001$ for each time point) (Fig. 3B). Pups from each litter were weighed every $24 \mathrm{~h}$ and average body weights were recorded. Pups nursed by ${ }^{++} O x t r$ dams showed a significantly lower average body weight than pups nursed by WT dams ( $P=0.0013$ for L4, $P=0.0011$ for L5, $P<0.001$ for L6-L14) (Fig. 3C). For cross-fostering experiments, newborn pups of ${ }^{++} \mathrm{Oxtr}$ dams were successfully fostered by WT mothers regardless of pup's genotype, but ${ }^{++} \mathrm{Oxtr}$ mothers failed to foster (Fig. 3D). When pups of ${ }^{++} \mathrm{Oxtr}$ dams were replaced with newborns from CD1 mothers, all of the pups showed signs of dehydration and stunted growth, compared to their littermates nurtured by CD1 mothers (Supplementary Fig. 1B). There was no evident sign of abnormal behavior from ${ }^{++} O x t r$ mothers with normal crouching over the pups. Survival failure of newborns is probably caused by insufficient milk secretory of ${ }^{++}$Oxtr mothers. This is supported by the reduced mRNA expression of Csn2 and Wap in ${ }^{++} \mathrm{Oxtr}$ mammary gland during lactation at L1, L4 and L18 (Fig. 3E).

To investigate what caused the insufficient milk yield, whole-mount and histological analysis of lactating mammary glands was performed. Results exhibited sparse alveolar units, small alveolar size and early involution of the epithelial cells into adipose tissue in ${ }^{++}$Oxtr mammary gland (Fig. 3F, G and Supplementary 


\begin{tabular}{|c|c|c|c|c|}
\hline $\begin{array}{l}\text { Journal of } \\
\text { Endocrinology }\end{array}$ & D Li et al. & $\begin{array}{l}\text { OXTR regulates mammary gland } \\
\text { though hormones }\end{array}$ & $239: 2$ & 126 \\
\hline
\end{tabular}

A

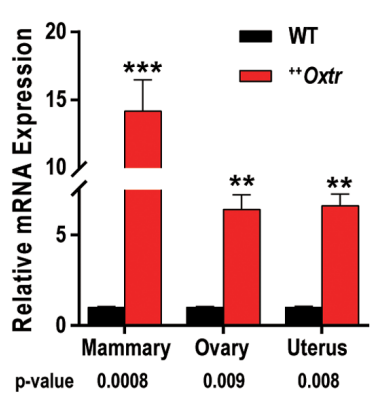

D

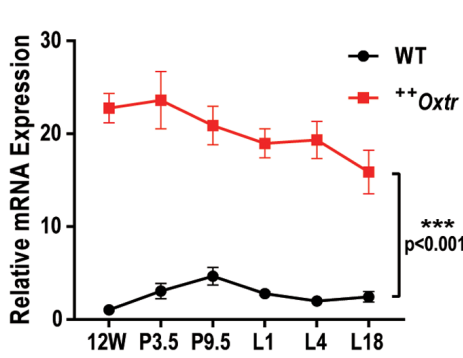

B

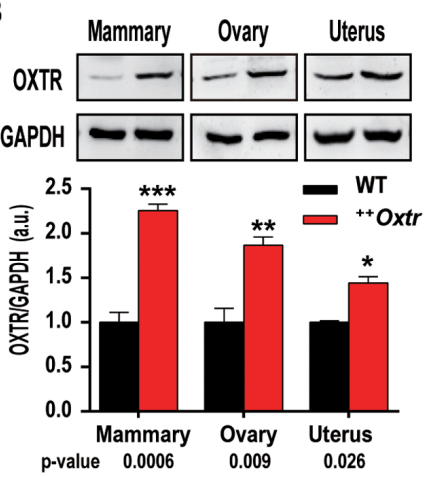

C

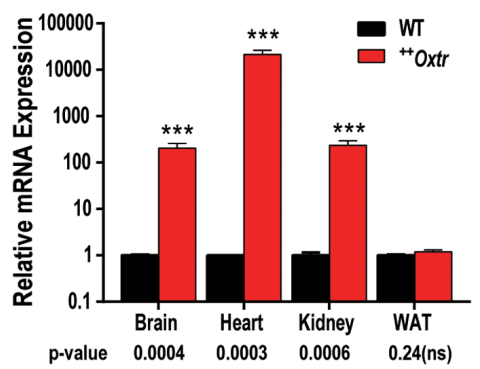

E
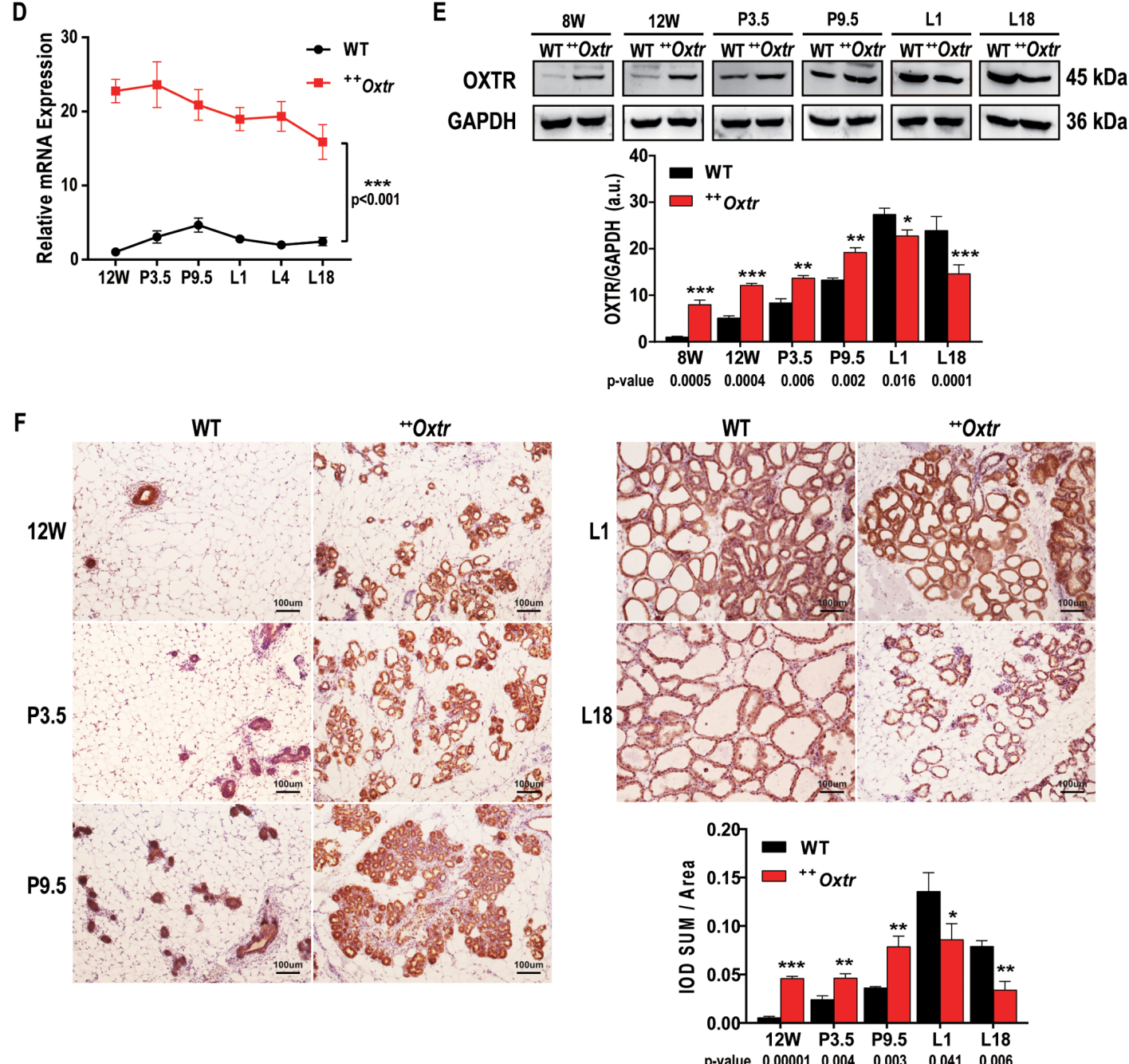

Figure 1

Overexpression of OXTR and localization during mammary gland development. Total RNA and protein were isolated from mammary gland (4rd pair), ovary, uterus, brain, heart, kidney and white adipose tissue (WAT) of WT and ${ }^{++}$Oxtr littermates at 12 weeks. (A) Oxtr mRNA expression in female reproductive system by RT-PCR, $n=4$ for each tissue. (B) OXTR expression in female reproductive system by Immunoblotting. GAPDH is served as a loading control. Protein quantifications using Image J, $n=4$ for each tissue. (C) Oxtr mRNA expression in brain, heart, kidney and WAT by RT-PCR, $n=3$ for each tissue. Mammary glands (4rd pair) were harvested from ${ }^{++}$Oxtr and WT littermates at 8 and 12 weeks (8 W and 12 W), pregnancy (P3.5 and P9.5) and lactation (L1, L4 and L18). (D) RT-PCR analysis of Oxtr mRNA expression in mammary glands during development, $n=3$ for each time point. (E) Immunoblotting analysis of OXTR in mammary gland. Protein quantifications using Image $J, n=4$ for each time point. (F) Immunochemistry staining of OXTR in mammary sections ( $5 \mu m$ ) and quantifications of immunostaining using Image Pro Plus. Nuclei were stained blue with hematoxylin. Scale bar: $100 \mu$ m. Original magnifications: $\times 20, n=3$ for each time point. Data are represented as mean \pm S.E.M. ${ }^{*} P<0.05, * * P<0.01, * * * P<0.001$, calculated using two-tailed unpaired $t$ test. 


\begin{tabular}{l|l|l|c|}
$\begin{array}{l}\text { Journal of } \\
\text { Endocrinology }\end{array}$ & $\begin{array}{l}\text { OXTR regulates mammary gland } \\
\text { though hormones }\end{array}$ & $\mathbf{2 3 9 : 2}$ \\
\hline
\end{tabular}

A

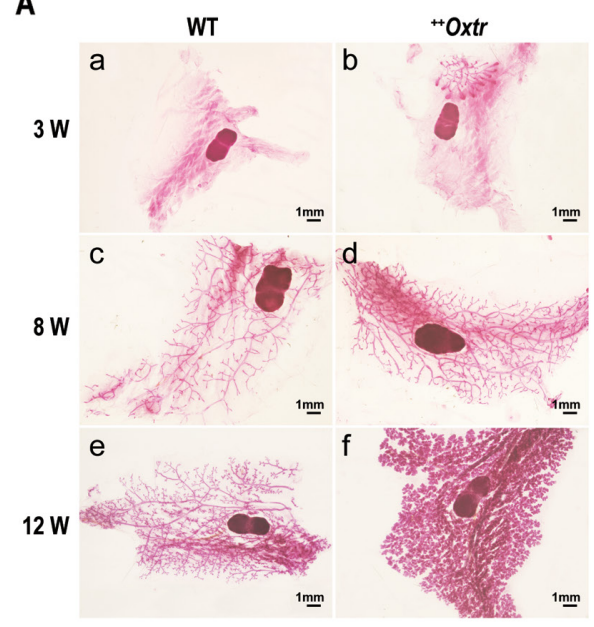

D

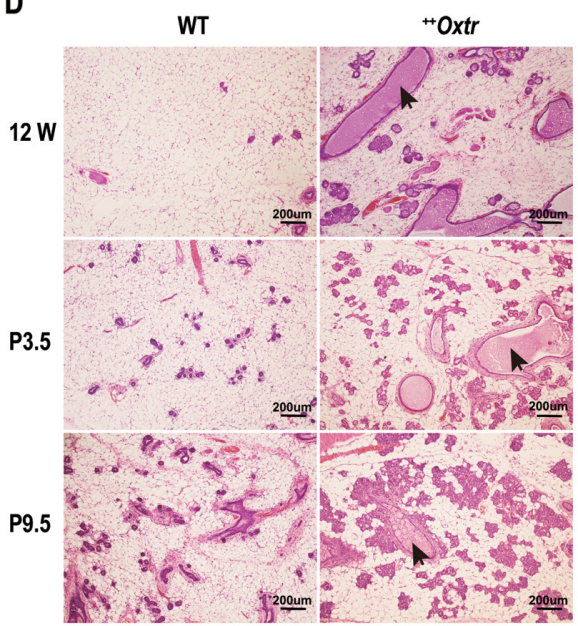

B

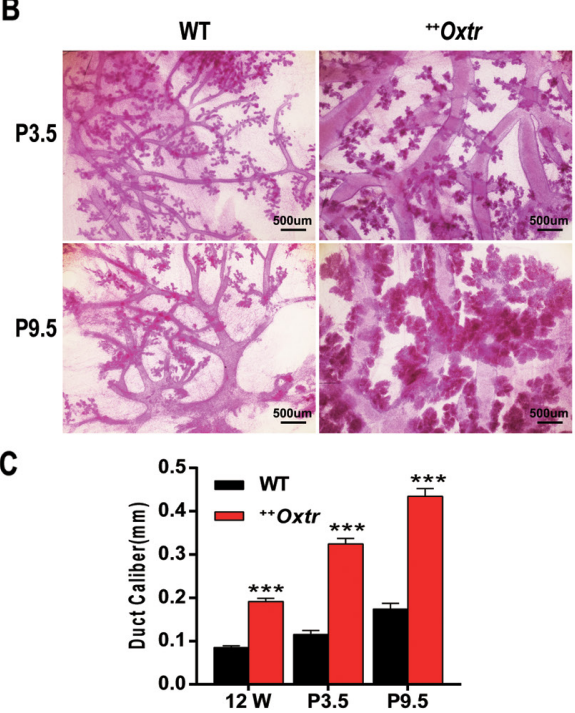

F
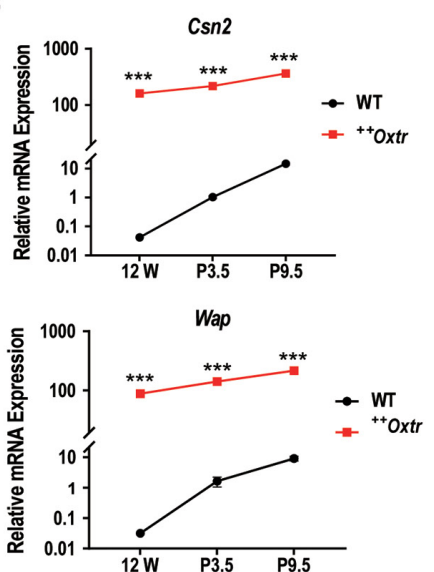

E

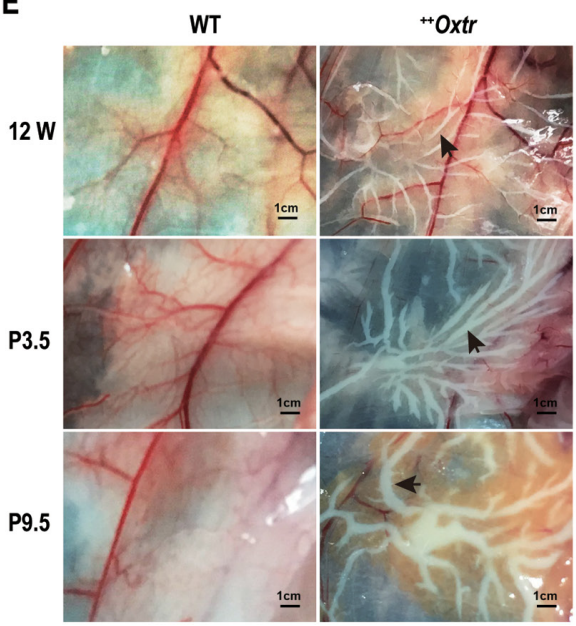

Figure 2

OXTR overexpression accelerates mammary gland development and milk production at non-pregnancy and pregnancy. Mammary glands (4rd pair) of ${ }^{++}$Oxtr and WT mice at 3, 8 and 12 weeks $(3,8,12 \mathrm{~W})$, pregnancy (P3.5, P9.5) were harvested. (A) Whole-mount staining of mammary gland at nonpregnancy $(3,8$ and $12 \mathrm{~W}$ ). Scale bar: $1 \mathrm{~mm}$. Original magnifications: $\times 1.25$. (B) Whole-mount staining of mammary gland at P3.5 and P9.5. Scale bar: $500 \mu \mathrm{m}$. Original magnifications: $\times 4$. (C) Mammary duct caliber $(\mathrm{mm})$ of $12 \mathrm{~W}, \mathrm{P3} .5$ and P9.5 WT and ${ }^{++}$Oxtr mice. Quantifications from whole-mount staining image using CAD software, $n=5$ for each time point. (D) H\&E staining of mammary gland from 12 W, P3.5 and P9.5 WT and ++Oxtr mice, duct full of proteinaceous material (arrows). Scale bar: $200 \mu \mathrm{m}$. Original magnifications: $\times 10$. (E) Macroscopic images of mammary gland (3rd pair), duct full of milk (arrows). Scale bar: $1 \mathrm{~cm}$. (F) Gene expression of major milk protein Csn2 and Wap during development (12 W, P3.5 and P9.5), $n=3$ for each time point. Data are represented as mean \pm S.E.M. $* * * P<0.001$, calculated using two-tailed unpaired $t$ test.

Fig. 1A). Involution-related genes (Stat3, Lif, Igfbp5, Mmp2 and Mmp3) were upregulated in the mammary glands of ${ }^{++} \mathrm{Oxtr}$ mice relative to WT in lactation (L1, L18) (Fig. 3H and Supplementary Fig. 1C), suggesting the early involution may have led to lactation failure.

\section{Prolactin and progesterone pathways are major players in OXTR-induced maldevelopment}

To determine whether the increase of OXTR in mammary gland or other organs caused abnormal mammary

\begin{tabular}{|c|c|}
\hline https://joe.bioscientifica.com & () 2018 Society for Endocrinology \\
\hline https://doi.org/10.1530/JOE-18-0356 & $\begin{array}{l}\text { Published by Bioscientifica Ltd. } \\
\text { Printed in Great Britain }\end{array}$ \\
\hline
\end{tabular}
Printed in Great Britain gland development, mammary gland transplantation experiments were performed. Whole-mount staining results showed that WT or ${ }^{++} O x t r$ donor epithelium did not make marked difference in mammary gland development (Fig. 4A). Instead, ${ }^{++}$Oxtr fat pad showed better support for both WT and ${ }^{++} \mathrm{Oxtr}$ donor mammary epithelium with increased outgrowth coverage (area of the fat pad repopulated by mammary epithelium) (Fig. 4A and B) and duct distension (Fig. 4A and C) than WT. These results indicate that the abnormal mammary gland development is mainly derived from the microenvironmental changes 
A

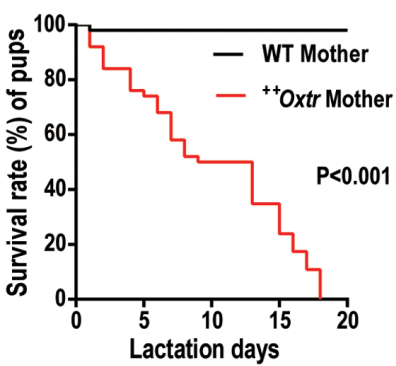

D

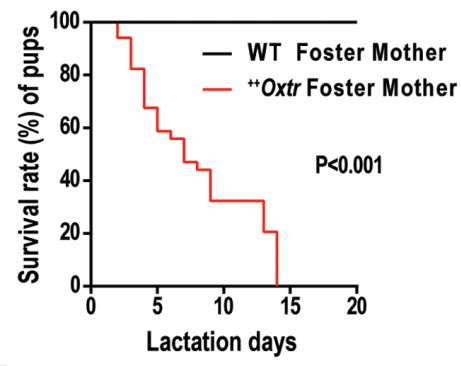

F

WT
B

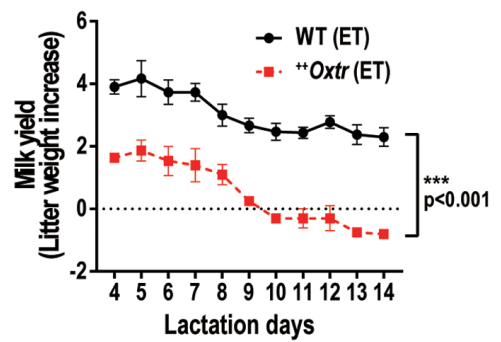

E

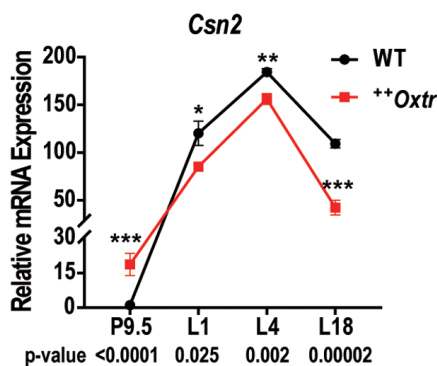

C
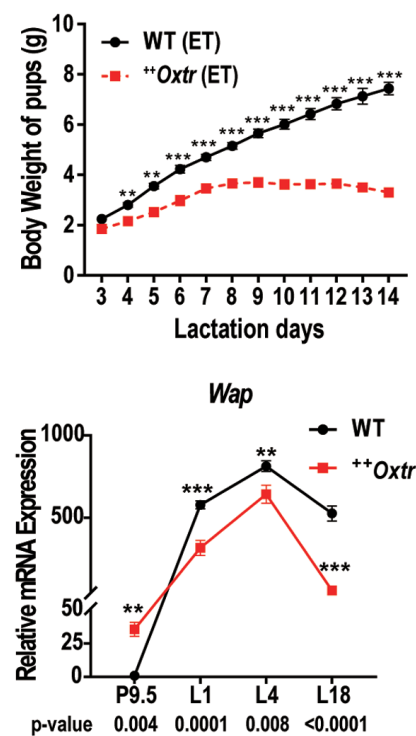

+Oxtr

L4

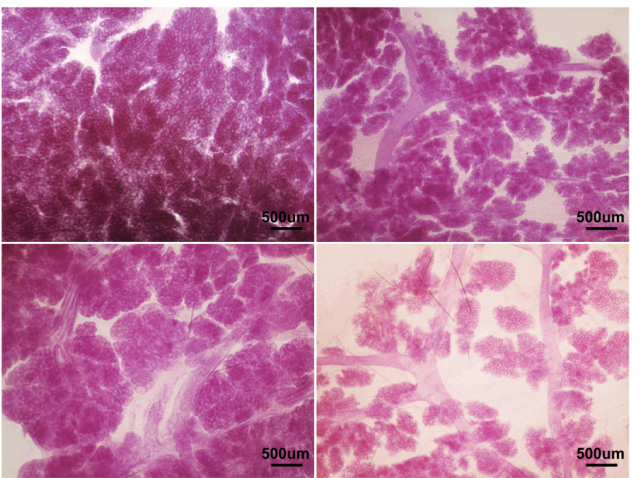

G

WT

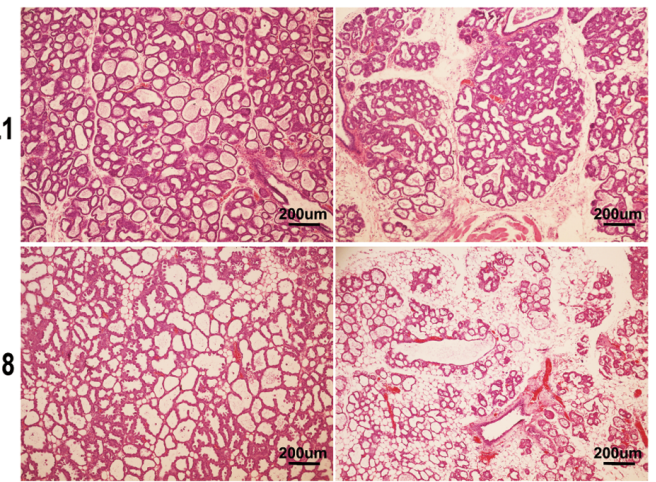

H

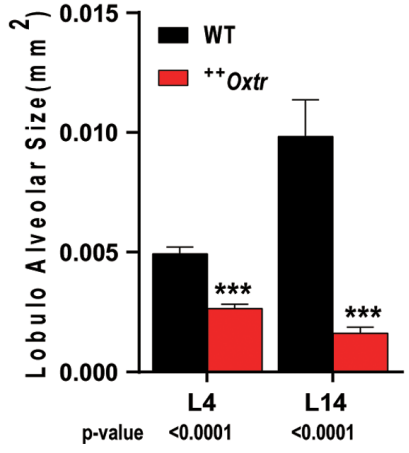

Stat3

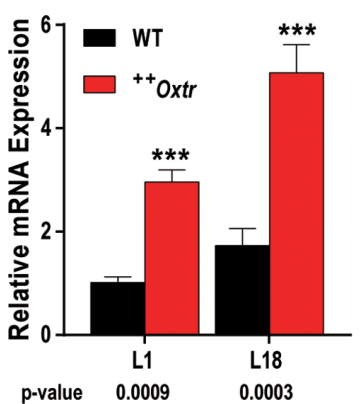

Igfbp5

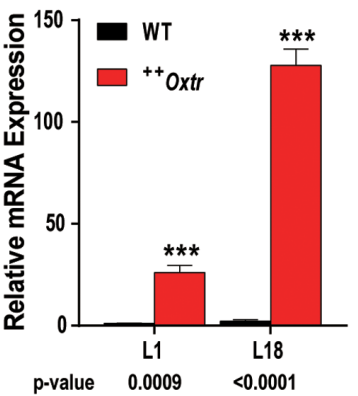

Figure 3

Impaired lobuloalveologenesis and early involution results in lactation failure of ++ Oxtr mice. (A) Survival analysis of newborn pups ( $n=51)$ from WT dams $(n=7)$ and newborn pups $(n=50)$ from ${ }^{++}$Oxtr dams $(n=9)$. (B) Milk yield by daily litter weight gain of newborn pups after embryos transferring (ET). 5 pups per litter were nursed by WT or ${ }^{++} O x t r$ dams $(n=4)$. (C) Average body weight of pups. 5 pups per litter were nursed by WT or ${ }^{++} O x t r$ dams $(n=4)$. (D) Survival analysis of pups $(n=37)$ nursed by WT dams $(n=5)$ and pups $(n=34)$ nursed by ${ }^{++}$Oxtr dams $(n=5)$ by cross-fostering experiments. (E) RT-PCR analysis of Csn2 and Wap mRNA in ++ Oxtr and WT mammary glands at P9.5, L1, L4, L18, $n=6$ for each time point. (F) Whole-mount staining of mammary gland and quantification of lobuloalveolar size in L4 and L14. Scale bar: $500 \mu \mathrm{m}$. Original magnifications: $\times 4, n=4$ for each time point. (G) H\&E staining of mammary gland in L1 and L18. Scale bar: $200 \mu \mathrm{m}$. Original magnifications: $\times 10 .(\mathrm{H})$ RT-PCR analysis of mammary gland involution-related gene expressions in L1 and L18, $n=6$ for each time point. Mammary glands (4rd pair) were harvested from ${ }^{++}$Oxtr and WT mice in lactation (L1, L4, L14 and L18). Data are represented as mean \pm S.E.M. ${ }^{*} P<0.05 ;{ }^{*} P<0.01 ;{ }^{* *} P<0.001$, calculated using two-tailed unpaired $t$ test and Log-rank (Mantel-Cox) test. 
A

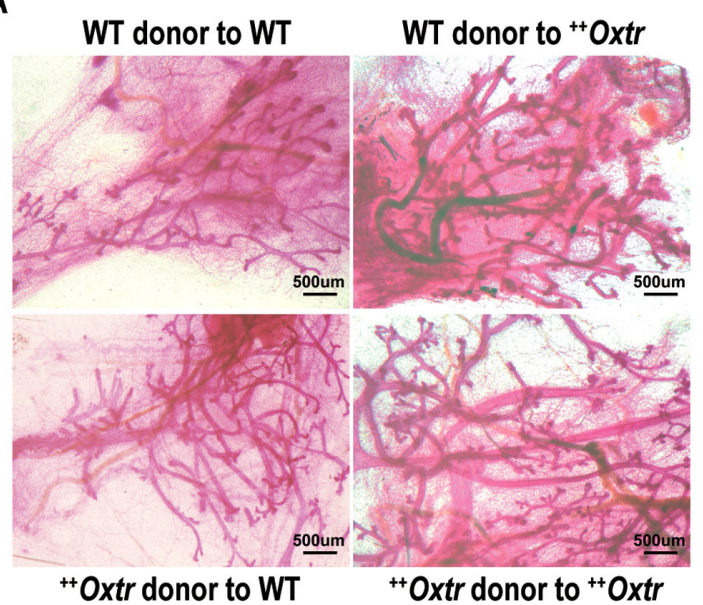

B

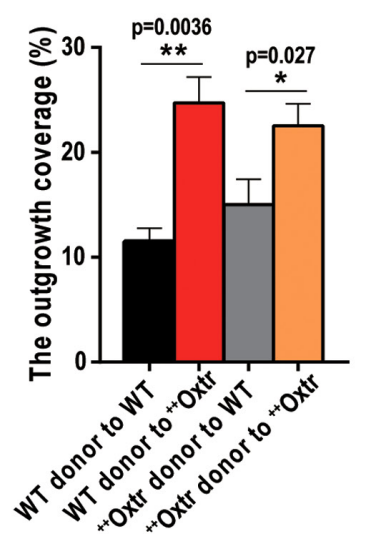

C

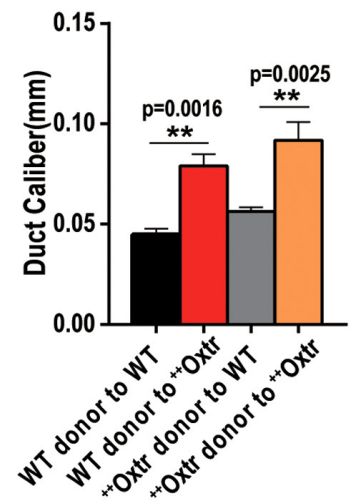

\section{Figure 4}

Mammary gland cross transplantation. The transplanted mammary (4rd pair) fat pads were harvested 8 weeks post transplantation from WT or ++ Oxtr mice. (A) Whole-mount staining of transplanted mammary gland. Scale bar: $500 \mu \mathrm{m}$. Original magnifications: $\times 4$. (B) Outgrowth coverage of the repopulated fat pad (percentage of duct and alveolar staining area) using Image Pro Plus, $n=3$. (C) Average duct calibers, $n=3$. Data are represented as mean \pm S.E.M. ${ }^{*} P<0.05 ; * * P<0.01$, calculated with one-way ANOVA.

in ${ }^{++}$Oxtr mice but not from the increased expression of OXTR in mammary gland.

Mammary gland development is mostly dependent on the hormonal environment including $17 \beta$-estradiol (E2), progesterone (P4) and prolactin (PRL). To determine whether these hormones play roles in the OXTR-induced changes, serum levels at various stages were analyzed by ELISA. No difference was found in $\mathrm{E} 2$ between virgin ${ }^{++} \mathrm{Oxtr}$ and WT (Supplementary Fig. 2A). However, progesterone was low through all stages in ${ }^{++}$Oxtr mice. In WT mice, serum progesterone reached a peak at pregnancy and dropped in lactation (Fig. 5A). WT prolactin increased during pregnancy and maintained a high level in lactation. In contrast, ${ }^{++} \mathrm{Oxtr}$ prolactin exhibited constantly higher level at non-pregnant stage $(P<0.0001$ for $12 \mathrm{~W}, 28 \mathrm{~W})$ but lower levels during pregnancy $(P=0.038$ for $P 3.5, P=0.006$ for p9.5) and lactation ( $P=0.034$ for L1, $P=0.006$ for L14) compared to WT (Fig. 5B). We examined RANKL expression at various stages by immunoblotting. In WT mice, RANKL expression was undetectable at non-pregnancy, gradually increased to a peak during pregnancy and dropped to a barely detectable level in lactation. In ${ }^{++}$Oxtr mice, RANKL expression was higher than WT at non-pregnancy and early pregnancy, but barely detectable in lactation (L1) and increased again with mammary involution in L18 (Fig. 5C). Results suggest that progesterone/RANKL, prolactin/RANKL pathways are both involved in the OXTR-induced mammary gland development.

To investigate whether OXTR overexpression has any effect on p-STAT5, we examined the expression and distribution of activated p-STAT5 (Tyr 694) in developing mammary glands. No difference was found in Stat5 (Stat5a and Stat $5 b$ ) mRNA levels between WT and ${ }^{++} O x$ tr mammary gland (Supplementary Fig. 2B and C). However, IHC results showed that OXTR overexpression induced higher levels of nuclear p-STAT5 in non-pregnant $(P=0.006$ for $12 \mathrm{~W})$ and early pregnant ${ }^{++}$Oxtr mammary epithelial cells $(P=0.023$ for P3.5, $P=0.004$ for p9.5) than WT (Fig. 5Da, $\mathrm{b}, \mathrm{c}, \mathrm{d}, \mathrm{e}, \mathrm{f}$ and $\mathrm{E})$. This result is consistent with the morphological changes and early milk production at nonpregnancy and pregnancy. Although nuclear p-STAT5 was detected in both WT and ${ }^{++}$Oxtr mammary epithelia during lactation, an earlier downregulation of p-STAT5 $(P=0.048$ for L1, $P=0.002$ for L18) was evident in ${ }^{++} O x t r$ mice than WT (Fig. 5Dg, h, i, j and E). This result is in agreement with the early morphological involution and low milk protein secretion in lactation. Immunoblotting analysis of p-STAT5 was in accord with IHC result (Fig. 5C). These patterns are correlated well with the functional changes, the early milk production at non-pregnancy and early termination in lactation. Results strongly suggest that prolactin/p-STAT5 signaling mediates the OXTR-induced abnormal mammary gland development.

\section{Progesterone can reverse the OXTR-induced changes through inhibition of PRL/p-STAT5 pathway}

To determine whether OXTR-induced changes were regulated by $\mathrm{P} 4,11$-week-old virgin $\mathrm{WT}$ and ${ }^{++} \mathrm{Oxtr}$ females were treated with $300 \mu \mathrm{g}(3 \mathrm{mg} / \mathrm{mL})$ P4 subcutaneously 


\begin{tabular}{l|l|l|c|}
$\begin{array}{l}\text { Journal of } \\
\text { Endocrinology }\end{array}$ & $\begin{array}{l}\text { OXTR regulates mammary gland } \\
\text { though hormones }\end{array}$ & $\mathbf{2 3 9 : 2}$ \\
\hline
\end{tabular}

A

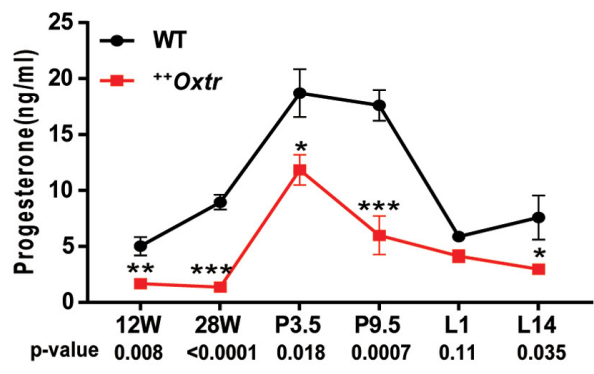

B

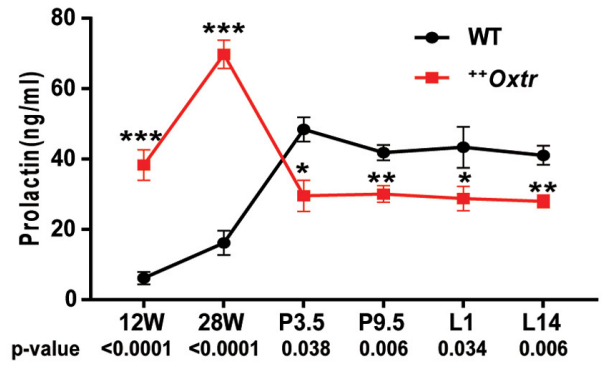

C

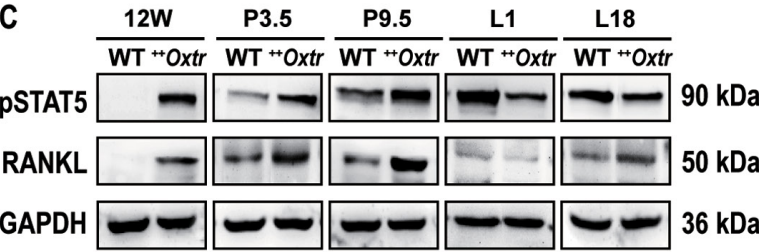

E

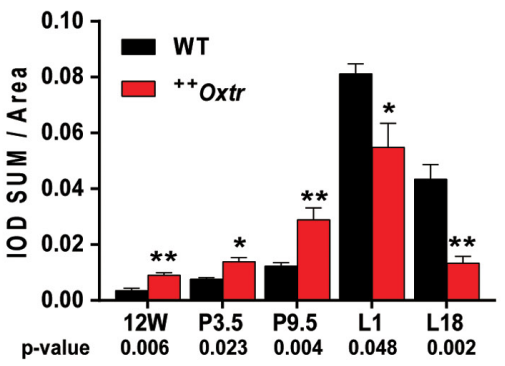

D

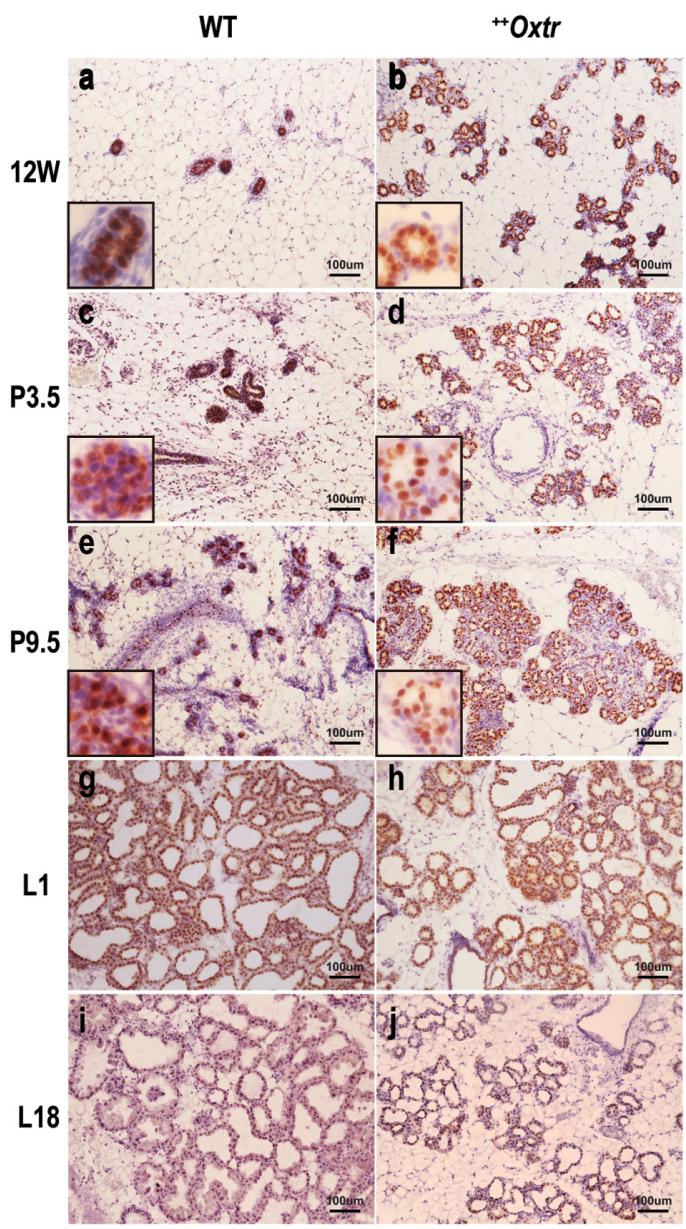

Figure 5

Progesterone/RANKL and prolactin/p-STAT5 are altered during mammary gland development in ${ }^{++} O x t r$ mice. (A) Serum progesterone levels in WT and ${ }^{++}$Oxtr mice at various stages, $n=5$ for each time point. (B) Serum prolactin levels in WT and ${ }^{++}$Oxtr mice at various stages, $n=5$ for each time point. (C) Immunoblotting analysis of p-STAT5 and RANKL in developing mammary gland from ${ }^{++} O x t r$ and WT mice. GAPDH is served as a loading control, $n=4$ for each time point. (D) Immunochemistry staining of p-STAT5 in developing mammary gland. The enlarged images at the lower left corner show the state of p-STAT5. Nuclei were stained blue with hematoxylin. Scale bar: $100 \mu \mathrm{m}$. Original magnifications: $\times 20$. (E) Quantifications of immunostaining using Image Pro Plus, $n=4$ for each time point. The mammary glands (4rd pair) were harvested from ${ }^{++}$Oxtr and WT littermates at 12 W, P3.5, P9.5, L1 and L18. Data are represented as mean \pm s.E.M. ${ }^{*} P<0.05 ; * * P<0.01, * * * P<0.001$, calculated using two-tailed unpaired $t$ test.

for seven consecutive days. P4 treatment significantly inhibited serum prolactin level in both WT $(P=0.0072)$ and ${ }^{++}$Oxtr mice $(P<0.0001)$ and reversed OXTR-induced hyperprolactinemia to a WT-like phenotype (Fig. 6A). P4 administration also rescued the decreased expression of its receptor (Pgr) mRNA seen in ${ }^{++}$Oxtr mice (Fig. 6B). RT-PCR and immunoblotting results both confirmed OXTR repression in mammary gland by $\mathrm{P} 4(P=0.0003)$ (Fig. 6C and D). P4 repressed nuclear p-STAT5 but enhanced RANKL expression (Fig. 6D). Whole-mount

\begin{tabular}{|r}
\hline https://joe.bioscientifica.com \\
https://doi.org/10.1530/JOE-18-0356 2018 Society for Endocrinology \\
Published by Bioscientifica Ltd. \\
Printed in Great Britain
\end{tabular}
Printed in Great Britain staining of mammary gland was performed to access the corresponding morphological changes. ${ }^{++} \mathrm{Oxtr}$ mice with P4 treatment exhibited attenuation of mammary gland development and morphologically similar to WT (Fig. 6E). P4-treated ${ }^{++} O x$ tr mice did not show distension of mature ducts filled with milk (Fig. 6F and G). Consistent with p-STAT5 expression and morphology, major milk protein gene expression (Wap and Csn2) was inhibited by $\mathrm{P} 4$ treatment $(P<0.0001)$ (Fig. $6 \mathrm{H})$. Overall, results demonstrate that progesterone can reverse the excessive 


\begin{tabular}{|l|l|l||c|c|}
\hline $\begin{array}{l}\text { Journal of } \\
\text { Endocrinology }\end{array}$ & D Li et al. & $\begin{array}{l}\text { OXTR regulates mammary gland } \\
\text { though hormones }\end{array}$ & $\mathbf{2 3 9 : 2}$ & $\mathbf{1 3 1}$ \\
\hline
\end{tabular}

A

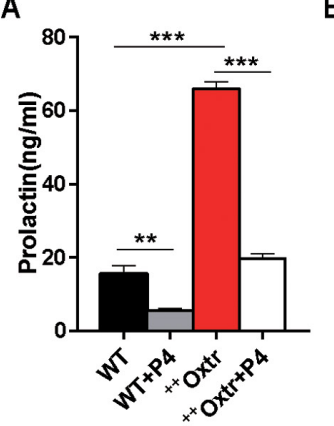

B

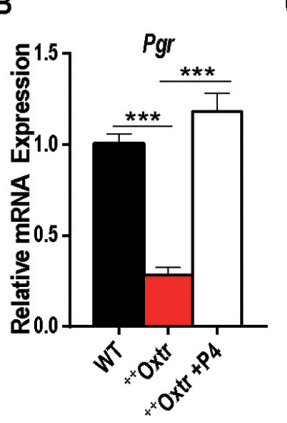

C

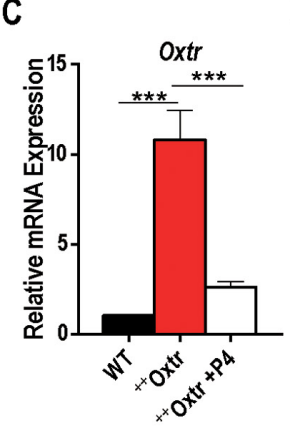

D

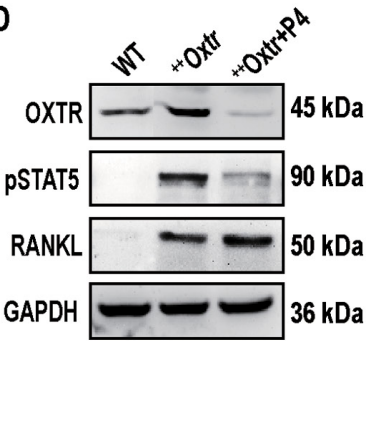

E

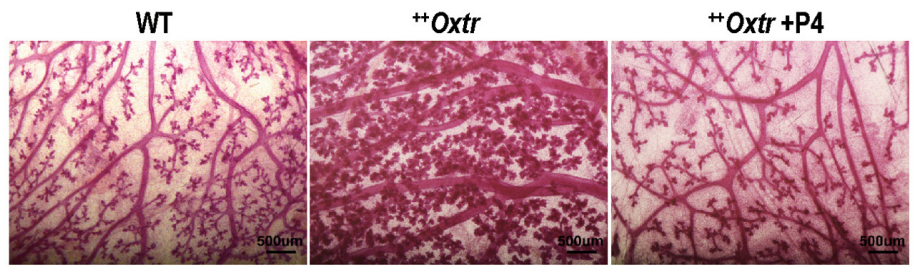

F

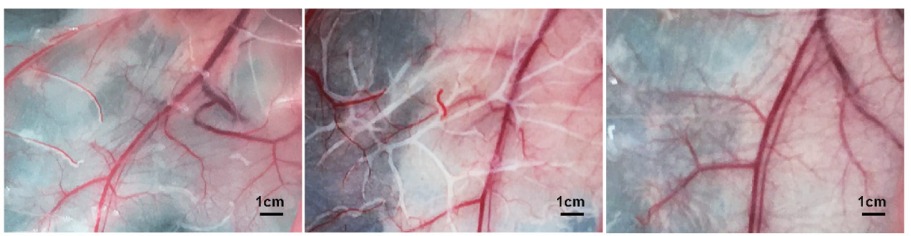

G

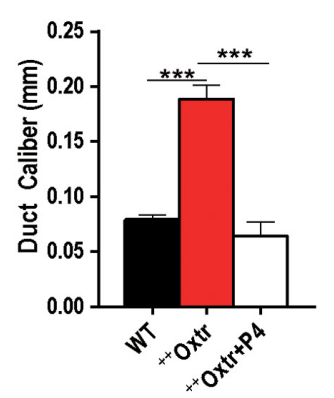

H

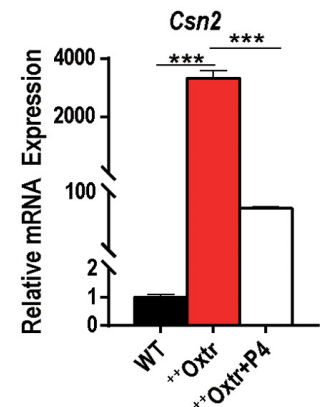

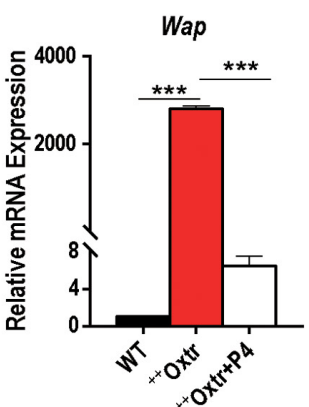

\section{Figure 6}

Progesterone can reverse the PRL/p-STAT5 effect at non-pregnancy. Eleven-weeks WT and ++Oxtr mice were treated with a vehicle or $300 \mu \mathrm{g}(3 \mathrm{mg} / \mathrm{mL}) \mathrm{P} 4$ for 7 days. The mammary glands (4rd pair) were harvested from ${ }^{++} O x t r$, hormone-treated ${ }^{++} O x t r$ and WT littermates at 12 W. (A) Serum prolactin levels of virgin WT and ${ }^{++}$Oxtr mice after P4 treatment, $n=3$. (B) RT-PCR analysis of Pgr expression in response to hormonal treatment, $n=3$.

(C) RT-PCR analysis of Oxtr expression after P4 treatment, $n=3$. (D) Immunoblotting analysis of OXTR, $p$-STAT5 and RANKL in virgin mammary gland after P4 treatment. (E) Whole-mount staining of mammary glands in response to hormonal treatment. Scale bar: $500 \mu$ m. Original magnifications: $\times 4$.

(F) Image of mammary gland (3rd pair) morphology in response to P4 treatment. Scale bar: $1 \mathrm{~cm}$. (G) Quantification of mammary duct caliber (mm) in response to P4 treatment, $n=3$. (H) RT-PCR analysis of major milk protein gene expression in mammary glands in response to P4 treatment, $n=3$. Data are represented as mean \pm S.E.M. $* * P<0.01 ; * * * P<0.001$, calculated with one-way ANOVA.

effect of OXTR on mammary gland morphology, gene expression and function by inhibiting prolactin-induced p-STAT5 pathway.

\section{Progesterone exacerbates but prolactin rescues the reduced PRL/p-STAT5 pathway during late pregnancy and lactation}

To investigate whether the early involution was caused by reduced prolactin, ${ }^{++} \mathrm{Oxtr}$ mice were treated with
$300 \mu \mathrm{g}(3 \mathrm{mg} / \mathrm{mL})$ P4 subcutaneously or $50 \mathrm{ng} / \mathrm{g}$ PRL intraperitoneally for three consecutive days at late pregnancy (P18.5, P19.5) and early lactation (L1). RT-PCR and immunoblotting results revealed that OXTR expression in mammary gland was inhibited by P4 $(P<0.0001)$, but not affected by PRL (Fig. 7A and C). Prlr mRNA was also inhibited by $\mathrm{P} 4(P<0.0001)$, but not affected by PRL (Fig. 7B). In addition, immunoblotting results also confirmed that p-STAT5 was repressed by P4 but enhanced by PRL (Fig. 7C). IHC results indicated 
A

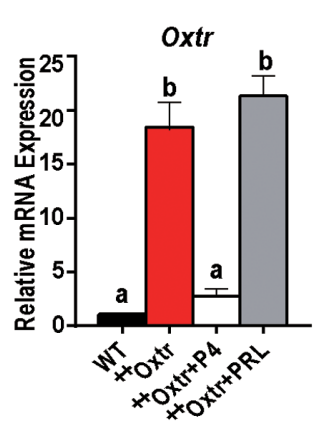

B

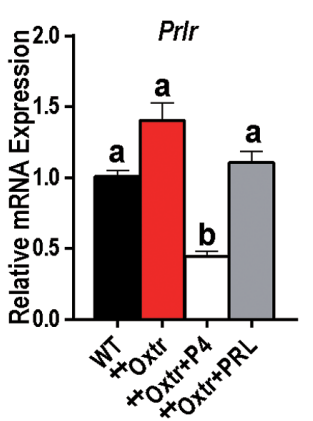

C

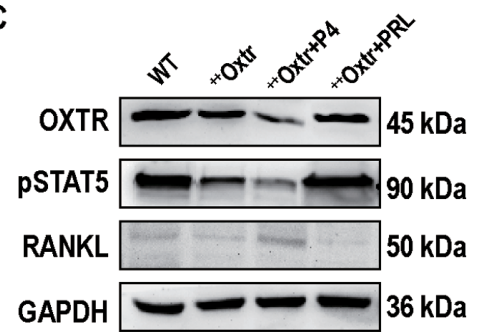

D

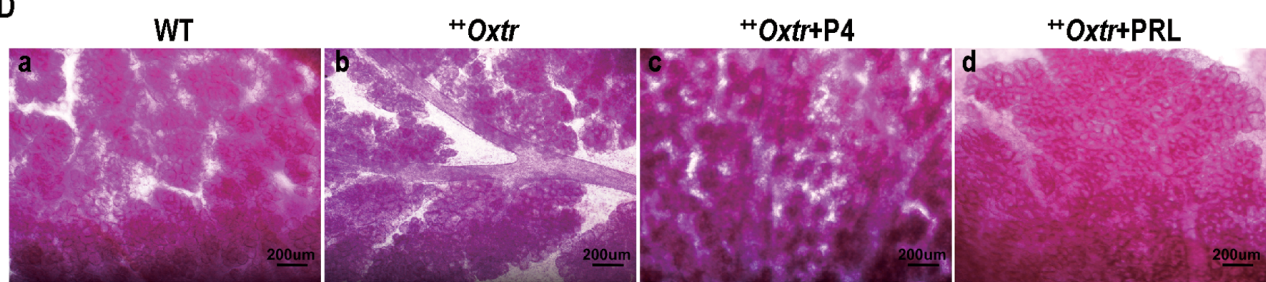

E

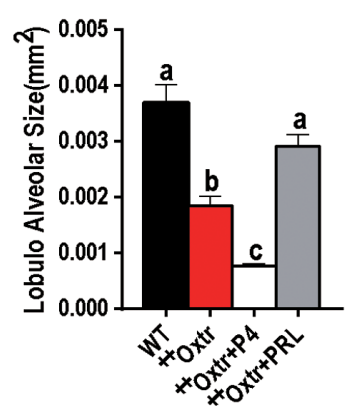

$\mathrm{F}$

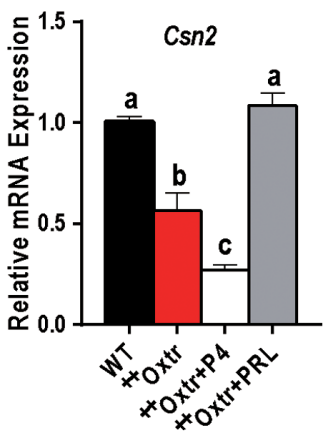

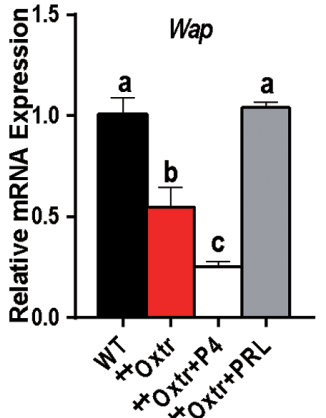

\section{Figure 7}

Progesterone can exacerbate but prolactin can rescue STAT5 pathway at late pregnancy and lactation. ${ }^{++} \mathrm{Oxtr}$ mice $\mathrm{were}$ treated with $300 \mu \mathrm{g}(3 \mathrm{mg} / \mathrm{mL}) \mathrm{P} 4$ or $50 \mathrm{ng} / \mathrm{g}$ PRL for 3 days at late pregnancy (P18.5, P19.5) and L1. The mammary glands (4rd pair) were harvested from ${ }^{++} \mathrm{Oxtr}$, hormone-treated ++Oxtr and WT littermates in lactation (L1). (A) RT-PCR analysis of Oxtr mRNA expression at L1 in response to hormonal treatment, $n=3$. (B) RT-PCR analysis of Prlr mRNA expression at L1 in response to hormonal treatment, $n=3$. (C) Immunoblotting analysis of OXTR, p-STAT5 and RANKL in L1 mammary gland after hormonal treatment. (D) Whole-mount staining of mammary glands in response to hormonal treatment. Scale bar: $200 \mu m$. Original magnifications: $\times 10$. (E) Quantification of alveolar size $\left(\mathrm{mm}^{2}\right), n=3$. (F) RT-PCR analysis of major milk protein gene expression in mammary glands in response to hormonal treatment, $n=3$. Data are represented as mean \pm S.E.M., calculated with one-way ANOVA.

that PRL rescued impaired morphological changes and restore the nuclear p-STAT5 expression (Supplementary Fig. 3A). RANKL was scarcely detected in lactation (L1) in either WT or ${ }^{++} \mathrm{Oxtr}$ mice. P4 treatment slightly enhanced RANKL expression, but not PRL (Fig. 7C). Whole-mount staining of mammary gland was performed to assess alveolar morphological changes following hormonal treatment. P4 treatment promoted alveolar proliferation but exacerbated the impaired alveolar differentiation and led to smaller alveolar size in ${ }^{++}$Oxtr mice (Fig. 7D, b, c and $\mathrm{E})$. This enhanced impairment resulted in death of all pups within $24 \mathrm{~h}$ after birth (Supplementary Fig. 3B). After prolactin treatment of ${ }^{++} \mathrm{Oxtr}$ mice, alveolar development was restored to the phenotype similar to WT (Fig. 7D and E). Similar to p-STAT5 expression and morphological changes, Wap and Csn2 mRNA was intensely inhibited by P4 but restored by PRL (Fig. 7F). These results demonstrate that $\mathrm{P} 4$ exacerbates alveolar development in ${ }^{++} \mathrm{Oxtr}$ mice, while PRL can rescue it through PRL/p-STAT5 pathway during lactation.

\section{Discussion}

In this study, we have confirmed that OXTR regulates mammary gland development. OXTR overexpression caused early mammary gland development and involution through disrupting hormone-regulated pathways. 
Overexpression of OXTR increased prolactin-induced STAT5 activation, leading to premature secretory differentiation and early milk production at non-pregnancy and early pregnancy. In lactation, ${ }^{++}$Oxtr mice exhibited decreased prolactin-induced STAT5 phosphorylation, resulting in a severe impairment in mammary gland differentiation, early involution of alveolar and failure of nurturing.

PRL/p-STAT5 pathway functions as a link between OXTR and mammary gland development in the study. PRL/p-STAT5 pathway is involved in alveolar development with lactogenic differentiation during pregnancy and lactation (Han et al. 1997, Cui et al. 2004). OXTR overexpression induced continuous higher PRL in nonpregnant ${ }^{++} \mathrm{Oxtr}$ mice. This altered micro-environmentaugmented PRL-induced phosphorylation as well as nuclear translocation of p-STAT5. Increased nuclear p-STAT5 contributed to differentiation of alveolar, demonstrated by transcription of milk protein genes (Csn2 and Wap) and early milk production at non-pregnancy and early pregnancy. Prolactin overproduction with unexpected milk secretion (galactorrhea) is the symptoms of hyperprolactinemia (Mancini et al. 2008). From pregnancy to lactation, WT PRL rose and maintained at very high levels. ${ }^{++} O x t r$ mice, instead, exhibited insufficient PRL at pregnancy and lactation, leading to low nuclear p-STAT5, impaired alveolar development, early involution and lactogenic failure. Indeed, PRL treatment rescued the impaired alveolar development by activation of PRL/p-STAT5 axis. Lactation failure in ${ }^{+} \mathrm{Oxtr}$ mice is similar to the phenotypes lacking prolactin $\left(\mathrm{Prl}^{---}\right)$, its receptor ( $\left.\mathrm{Prlr}^{--}\right)$, Jak2 (Jak2-/-) and lack of activated STAT5 (Horseman et al. 1997, Liu et al. 1997, Ormandy et al. 1997, Parganas et al. 1998, Teglund et al. 1998, Wagner et al. 2004). In summary, OXTR overexpression under $\beta$-actin promoter induces abnormal mammary gland development through PRL-induced STAT5 phosphorylation.

A link between OXTR and progesterone/RANKL is also emerged from our study. The progesterone-RANKL axis is involved in mammary epithelium proliferation (Beleut et al. 2010). OXTR overexpression caused low serum progesterone at various development stages, indicating OXTR plays a negative role in the regulation of progesterone. Surprisingly, RANKL as a downstream mediator of progesterone to promote cell proliferation was upregulated in non-pregnant and early pregnant ${ }^{++}$Oxtr mammary gland. Since RANKL expression is regulated by both progesterone and prolactin (Fata et al. 2000, Mulac-Jericevic et al. 2003), it is likely that prolactin axis causes the increase of RANKL despite low progesterone at non-pregnancy and early pregnancy. Undetectable RANKL in lactation may be due to low progesterone and blockage of prolactin axis to induce RANKL. The hypothesis is supported by the fact that progesterone treatment increased RANKL expression and promoted proliferation, but prolactin treatment had no effect on RANKL expression in lactation. RANKL likely serves as a balance between progesterone and prolactin action in mammary gland. Progesterone treatment of ${ }^{++}$Oxtr females at different development stages

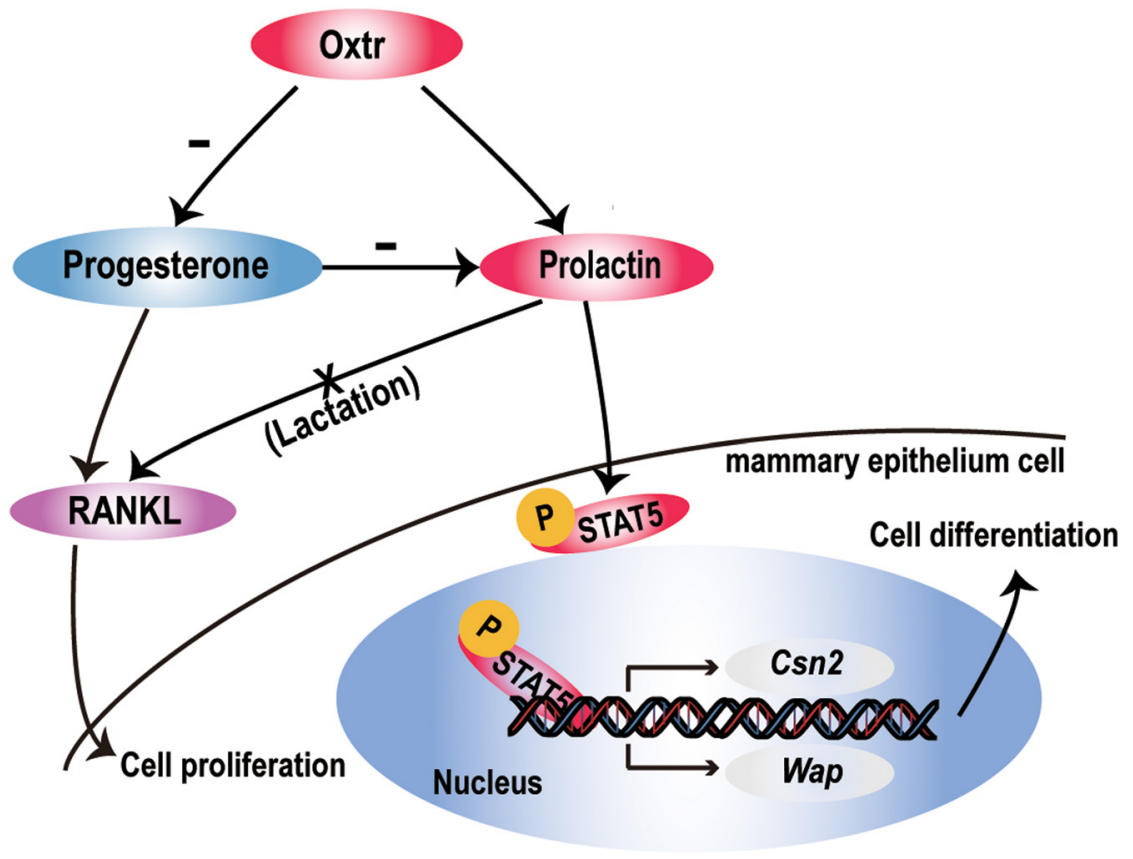

\section{Figure 8}

Role model of OXTR in mammary gland development. OXTR regulates mammary gland development through progesterone/RANKL axis and PRL/PSTAT5 axis. OXTR regulates PRL/p-STAT5 pathway. Activated STAT5 ( $p$-STAT5) translocates to nucleus to regulate the transcription of Csn2 and Wap. The expression of milk protein Wap and Csn2 marks the mammary epithelium differentiation and maturation. OXTR overexpression inhibits progesterone level. Progesterone/RANKL pathway mediates mammary epithelium proliferation but inhibits PRL/p-STAT5-induced differentiation. RANKL is regulated by both prolactin and progesterone, but prolactin-induced RANKL is prevented in lactation. A full colour version of this figure is available at https://doi.org/10.1530/JOE-18-0356. 
suppressed OXTR expression in mammary gland. This is consistent with the view that progesterone acts as a negative regulator of OXTR in mammary gland (Grazzini et al. 1998).

A crosstalk is present between progesterone/ RANKL and PRL/p-STAT5 in OXTR-induced abnormal mammary gland development. In WT, progesterone and prolactin both rose during pregnancy and orchestrated proliferation and differentiation of mammary epithelium in preparation for lactation. Prolactin was maintained at a high level, while a precipitous decrease of progesterone happened at parturition (Fig. 5A and B). The drop is necessary for prolactin-controlled events associated with lactogenic differentiation (Kuhn 1969, Virgo \& Bellward 1974). Progesterone treatment of ${ }^{++} O x t r$ mice at late pregnancy and lactation aggravated the inhibition on PRL/p-STAT5 axis, worsen the impaired alveolar differentiation and led to offspring death within $24 \mathrm{~h}$ of birth (Supplementary Fig. 3B). Activated PRL/p-STAT5 axis and increased secretory differentiation in non-pregnant ${ }^{+}$Oxtr mice may be due to the low progesterone. Indeed, progesterone treatment at non-pregnancy reversed the OXTR-induced secretory activation by inhibiting PRL/p-STAT5 axis. Progesterone plays a negative role in OXTR-regulated prolactin/STAT5 pathways. Since RANKL can inhibit prolactin-induced lactogenic activity through STAT5 (Cordero et al. 2016), blockage of prolactin-induced RANKL at late pregnancy and lactation is important. Collectively, mammary gland development depends on the balance of proliferation and differentiation. OXTR overexpression disrupts this balance.

The results of mammary gland transplantation demonstrated that abnormal mammary gland development was mainly dependent on OXTR-induced hormonal changes but not OXTR in mammary gland. OXTR in brain responds to exogenous oxytocin and stimulates prolactin release from pituitary lactotroph (Tabak et al. 2010, Kennett \& McKee 2012). Neuron-specific overexpression of OXTR may shed light on this.

Investigation of OXTR on mammary gland development provides a working model that OXTRinduced accelerated mammary gland development at non-pregnancy and early pregnancy but lactation failure through progesterone/RANKL and PRL/p-STAT5 pathway (Fig. 8). OXTR regulates PRL/p-STAT5 pathway to act on mammary epithelium differentiation, mammary gland maturation and milk production. OXTR overexpression inhibits progesterone secretion and disrupts the balance between progesterone and PRL/p-STAT5. Progesterone/ RANKL pathway mediates mammary epithelium proliferation but inhibits PRL/p-STAT5 induced differentiation. RANKL is regulated by both prolactin and progesterone, but prolactin-induced RANKL is prevented in lactation. OXTR induces abnormal mammary gland development through hormonal changes.

\section{Supplementary data}

This is linked to the online version of the paper at https://doi.org/10.1530/ JOE-18-0356.

\section{Declaration of interest}

The authors declare that there is no conflict of interest that could be perceived as prejudicing the impartiality of the research reported.

\section{Funding}

This work is supported in whole or in part by National Natural Science Foundation of China (81270953 and 31301189), Research Funds for Central Universities (12QNJJ015 and 10JCXK001), Research Fund for Doctoral Program of Higher Education of China (20130043120010), Science-Technology Foundation for Young Scientist of Jilin Province (20130522003JH), Program of International S\&T cooperation (2015 DFA31580) and the Natural Science Foundation of Jilin Province (20160101344JC). The funders had no role in study design, data collection and analysis or decision to publish.

\section{Author contribution statement}

$Y$ W Z, D L, X C F, L Q Z and Y J conceived and designed the experiments. $D L, Y J, C L Z, Y P Y, M J S, J Z$ and $M J Z$ carried out experiments. $D L, H H J$ and $A L Y$ analyzed the data. $D L$ and $Y C$ contributed reagents/ materials/analysis tools. $Y \mathrm{~W} \mathrm{Z}$ and $\mathrm{D} L$ wrote the paper. All authors were involved in revising the manuscript and had final approval of the submitted and published versions.

\section{Acknowledgements}

The authors are very grateful to Xiulu Lv for microinjection and mouse colony maintenance. They thank the animal care facility of Transgenic Research Center of Northeast Normal University.

\section{References}

Ali S \& Ali S 1998 Prolactin receptor regulates Stat5 tyrosine phosphorylation and nuclear translocation by two separate pathways. Journal of Biological Chemistry 273 7709-7716. (https://doi. org/10.1074/jbc.273.13.7709)

Asselin-Labat ML, Vaillant F, Sheridan JM, Pal B, Wu D, Simpson ER, Yasuda H, Smyth GK, Martin TJ, Lindeman GJ, et al. 2010 Control of mammary stem cell function by steroid hormone signalling. Nature 465 798-802. (https://doi.org/10.1038/nature09027)

Beleut M, Rajaram RD, Caikovski M, Ayyanan A, Germano D, Choi Y, Schneider P \& Brisken C 2010 Two distinct mechanisms underlie 
progesterone-induced proliferation in the mammary gland. PNAS 107 2989-2994. (https://doi.org/10.1073/pnas.0915148107)

Brisken C, Park S, Vass T, Lydon JP, O'Malley BW \& Weinberg RA 1998 A paracrine role for the epithelial progesterone receptor in mammary gland development. PNAS 95 5076-5081. (https://doi.org/10.1073/ pnas.95.9.5076)

Cardiff RD, Moghanaki D \& and Jensen RA 2000 Genetically engineered mouse models of mammary intraepithelial neoplasia. Journal of Mammary Gland Biology and Neoplasia 5 421-437. (https://doi. org/10.1023/A:1009534129331)

Chapman RS, Lourenco PC, Tonner E, Flint DJ, Selbert S, Takeda K, Akira S, Clarke AR \& Watson CJ 1999 Suppression of epithelial apoptosis and delayed mammary gland involution in mice with a conditional knockout of Stat3. Genes and Development 13 2604-2616. (https://doi.org/10.1101/gad.13.19.2604)

Cordero A, Pellegrini P, Sanz-Moreno A, Trinidad EM, Serra-Musach J, Deshpande C, Dougall WC, Pujana MA \& Gonzalez-Suarez E 2016 Rankl impairs lactogenic differentiation through inhibition of the prolactin/Stat5 pathway at midgestation. Stem Cells 34 1027-1039. (https://doi.org/10.1002/stem.2271)

Cui Y, Riedlinger G, Miyoshi K, Tang W, Li C, Deng CX, Robinson GW \& Hennighausen L 2004 Inactivation of Stat5 in mouse mammary epithelium during pregnancy reveals distinct functions in cell proliferation, survival, and differentiation. Molecular and Cellular Biology 24 8037-8047. (https://doi.org/10.1128/MCB.24.18.80378047.2004)

Dunphy KA, Tao L \& Jerry DJ 2010. Mammary epithelial transplant procedure. Journal of Visualized Experiments 40 1849-1856.

Fata JE, Kong YY, Li J, Sasaki T, Irie-Sasaki J, Moorehead RA, Elliott R, Scully S, Voura EB, Lacey DL, et al. 2000 The osteoclast differentiation factor osteoprotegerin-ligand is essential for mammary gland development. Cell 103 41-50. (https://doi.org/10.1016/S00928674(00)00103-3)

Fata JE, Leco KJ, Voura EB, Yu HY, Waterhouse P, Murphy G, Moorehead RA \& Khokha R 2001 Accelerated apoptosis in the Timp3-deficient mammary gland. Journal of Clinical Investigation 108 831-841. (https://doi.org/10.1172/JCI13171)

Fernandez-Valdivia R, Mukherjee A, Creighton CJ, Buser AC, DeMayo FJ Edwards DP \& Lydon JP 2008 Transcriptional response of the murine mammary gland to acute progesterone exposure. Endocrinology 149 6236-6250. (https://doi.org/10.1210/en.2008-0768)

Gouilleux F, Wakao H, Mundt M \& Groner B 1994 Prolactin induces phosphorylation of Tyr694 of Stat5 (MGF), a prerequisite for DNA binding and induction of transcription. EMBO Journal 13 4361-4369. (https://doi.org/10.1002/j.1460-2075)

Grazzini E, Guillon G, Mouillac B \& Zingg HH 1998 Inhibition of oxytocin receptor function by direct binding of progesterone. Nature 392 509-512. (https://doi.org/10.1038/33176)

Gutkowska J, Jankowski M, Lambert C, Mukaddam-Daher S, Zingg HH \& McCann SM 1997 Oxytocin releases atrial natriuretic peptide by combining with oxytocin receptors in the heart. PNAS 94 11704-11709. (https://doi.org/10.1073/pnas.94.21.11704)

Han Y, Watling D, Rogers NC \& Stark GR 1997 JAK2 and STAT5, but not JAK1 and STAT1, are required for prolactin-induced beta-lactoglobulin transcription. Molecular Endocrinology 11 1180-1188. (https://doi. $\operatorname{org} / 10.1210 /$ mend.11.8.9952)

Helmer H, Hackl T, Schneeberger C, Knofler M, Behrens O, Kaider A \& Husslein P 1998 Oxytocin and vasopressin 1a receptor gene expression in the cycling or pregnant human uterus. American Journal of Obstetrics and Gynecology 179 1572-1578. (https://doi.org/10.1016/ S0002-9378(98)70027-4)

Hidema S, Fukuda T, Hiraoka Y, Mizukami H, Hayashi R, Otsuka A, Suzuki S, Miyazaki S \& Nishimori K 2016 Generation of Oxtr cDNA(HA)-ires-Cre mice for gene expression in an oxytocin receptor specific manner. Journal of Cellular Biochemistry 117 1099-1111. (https://doi.org/10.1002/jcb.25393)
Horseman ND, Zhao W, Montecino-Rodriguez E, Tanaka M, Nakashima K, Engle SJ, Smith F, Markoff E \& Dorshkind K 1997 Defective mammopoiesis, but normal hematopoiesis, in mice with a targeted disruption of the prolactin gene. EMBO Journal $\mathbf{1 6}$ 6926-6935. (https://doi.org/10.1093/emboj/16.23.6926)

Insel TR, Young L, Witt DM \& Crews D 1993 Gonadal steroids have paradoxical effects on brain oxytocin receptors. Journal of Neuroendocrinology 5 619-628. (https://doi. org/10.1111/j.1365-2826.1993.tb00531.x)

Joshi PA, Jackson HW, Beristain AG, Di Grappa MA, Mote PA, Clarke CL, Stingl J, Waterhouse PD \& Khokha R 2010 Progesterone induces adult mammary stem cell expansion. Nature 465 803-807. (https://doi. org/10.1038/nature09091)

Kasahara Y, Tateishi Y, Hiraoka Y, Otsuka A, Mizukami H, Ozawa K, Sato K, Hidema S \& Nishimori K 2015 Role of the oxytocin receptor expressed in the rostral medullary raphe in thermoregulation during cold conditions. Frontiers in Endocrinology 6 180. (https://doi. $\operatorname{org} / 10.3389 /$ fendo.2015.00180)

Kennett JE \& McKee DT 2012 Oxytocin: an emerging regulator of prolactin secretion in the female rat. Journal of Neuroendocrinology $\mathbf{2 4}$ 403-412. (https://doi.org/10.1111/j.1365-2826.2011.02263.x)

Kimura T, Tanizawa O, Mori K, Brownstein MJ \& Okayama H 1992 Structure and expression of a human oxytocin receptor. Nature 356 526-529. (https://doi.org/10.1038/356526a0)

Kimura T, Ito Y, Einspanier A, Tohya K, Nobunaga T, Tokugawa Y, Takemura M, Kubota Y, Ivell R, Matsuura N, et al. 1998 Expression and immunolocalization of the oxytocin receptor in human lactating and non-lactating mammary glands. Human Reproduction 13 2645-2653. (https://doi.org/10.1093/humrep/13.9.2645)

Kritikou EA, Sharkey A, Abell K, Came PJ, Anderson E, Clarkson RW \& Watson CJ 2003 A dual, non-redundant, role for LIF as a regulator of development and STAT3-mediated cell death in mammary gland. Development 130 3459-3468. (https://doi.org/10.1242/dev.00578)

Kuhn NJ 1969 Progesterone withdrawal as the lactogenic trigger in the rat. Journal of Endocrinology 44 39-54. (https://doi.org/10.1677/ joe.0.0440039)

Li S \& Rosen JM 1995 Nuclear factor I and mammary gland factor (STAT5) play a critical role in regulating rat whey acidic protein gene expression in transgenic mice. Molecular and Cellular Biology 15 2063-2070. (https://doi.org/10.1128/ MCB.15.4.2063)

Liu X, Robinson GW, Gouilleux F, Groner B \& Hennighausen L 1995 Cloning and expression of Stat5 and an additional homologue (Stat5b) involved in prolactin signal transduction in mouse mammary tissue. PNAS 92 8831-8835. (https://doi.org/10.1073/ pnas.92.19.8831)

Liu X, Robinson GW, Wagner KU, Garrett L, Wynshaw-Boris A \& Hennighausen L 1997 Stat5a is mandatory for adult mammary gland development and lactogenesis. Genes and Development 11 179-186. (https://doi.org/10.1101/gad.11.2.179)

Macias H \& Hinck L 2012 Mammary gland development. Wiley Interdisciplinary Reviews: Developmental Biology 1 533-557. (https://doi. org/10.1002/wdev.35)

Malumbres M, Mangues R, Ferrer N, Lu S \& Pellicer A 1997 Isolation of high molecular weight DNA for reliable genotyping of transgenic mice. BioTechniques 22 1114-1119. (https://doi. org/10.2144/97226st03)

Mancini T, Casanueva FF \& Giustina A 2008 Hyperprolactinemia and prolactinomas. Endocrinology and Metabolism Clinics of North America 37 67-99. (https://doi.org/10.1016/j.ecl.2007.10.013)

Marshall PN \& Horobin RW 1973 The mechanism of action of 'mordant' dyes - a study using preformed metal complexes. Histochemie. Histochemistry. Histochimie 35 361-371. (https://doi.org/10.1007/ BF00310675)

Mulac-Jericevic B, Lydon JP, DeMayo FJ \& Conneely OM 2003 Defective mammary gland morphogenesis in mice lacking the progesterone
(C) 2018 Society for Endocrinology Published by Bioscientifica Ltd. Printed in Great Britain 
receptor B isoform. PNAS 100 9744-9749. (https://doi.org/10.1073/ pnas.1732707100)

Ning Y, Hoang B, Schuller AG, Cominski TP, Hsu MS, Wood TL \& Pintar JE 2007 Delayed mammary gland involution in mice with mutation of the insulin-like growth factor binding protein 5 gene. Endocrinology 148 2138-2147. (https://doi.org/10.1210/en.2006-0041)

Ormandy CJ, Camus A, Barra J, Damotte D, Lucas B, Buteau H, Edery M, Brousse N, Babinet C, Binart N, et al. 1997 Null mutation of the prolactin receptor gene produces multiple reproductive defects in the mouse. Genes and Development 11 167-178. (https://doi.org/10.1101/ gad.11.2.167)

Palmer CA, Neville MC, Anderson SM \& McManaman JL 2006 Analysis of lactation defects in transgenic mice. Journal of Mammary Gland Biology and Neoplasia 11 269-282. (https://doi.org/10.1007/s10911-006-9023-3)

Parganas E, Wang D, Stravopodis D, Topham DJ, Marine JC, Teglund S, Vanin EF, Bodner S, Colamonici OR, van Deursen JM, et al. 1998 Jak2 is essential for signaling through a variety of cytokine receptors. Cell 93 385-395. (https://doi.org/10.1016/S0092-8674(00)81167-8)

Plante I, Stewart MK \& Laird DW 2011 Evaluation of mammary gland development and function in mouse models. Journal of Visualized Experiments 53 2828-2833. (https://doi.org/10.3791/2828)

Ramos-Vara JA 2005 Technical aspects of immunohistochemistry. Veterinary Pathology 42 405-426. (https://doi.org/10.1354/vp.42-4405)

Renart J, Reiser J \& Stark GR 1979 Transfer of proteins from gels to diazobenzyloxymethyl-paper and detection with antisera: a method for studying antibody specificity and antigen structure. PNAS $\mathbf{7 6}$ 3116-3120. (https://doi.org/10.1073/pnas.76.7.3116)

Schmitt-Ney M, Doppler W, Ball RK \& Groner B 1991 Beta-casein gene promoter activity is regulated by the hormone-mediated relief of transcriptional repression and a mammary-gland-specific nuclear factor. Molecular and Cellular Biology 11 3745-3755. (https://doi. org/10.1128/MCB.11.7.3745)

Srivastava S, Matsuda M, Hou Z, Bailey JP, Kitazawa R, Herbst MP \& Horseman ND 2003 Receptor activator of NF-kappaB ligand induction via Jak2 and Stat5a in mammary epithelial cells. Journal of Biological Chemistry 278 46171-46178. (https://doi.org/10.1074/jbc. M308545200)

Sympson CJ, Talhouk RS, Alexander CM, Chin JR, Clift SM, Bissell MJ \& Werb Z 1994 Targeted expression of stromelysin-1 in mammary gland provides evidence for a role of proteinases in branching morphogenesis and the requirement for an intact basement membrane for tissue-specific gene expression. Journal of Cell Biology 125 681-693. (https://doi.org/10.1083/jcb.125.3.681)

Tabak J, Gonzalez-Iglesias AE, Toporikova N, Bertram R \& Freeman ME 2010 Variations in the response of pituitary lactotrophs to oxytocin during the rat estrous cycle. Endocrinology 151 1806-1813. (https:// doi.org/10.1210/en.2009-1267)

Takayanagi Y, Yoshida M, Bielsky IF, Ross HE, Kawamata M, Onaka T, Yanagisawa T, Kimura T, Matzuk MM, Young LJ, et al. 2005 Pervasive social deficits, but normal parturition, in oxytocin receptordeficient mice. PNAS 102 16096-16101. (https://doi.org/10.1073/ pnas.0505312102)

Teglund S, McKay C, Schuetz E, van Deursen JM, Stravopodis D, Wang D, Brown M, Bodner S, Grosveld G \& Ihle JN 1998 Stat5a and Stat5b proteins have essential and nonessential, or redundant, roles in cytokine responses. Cell 93 841-850. (https://doi.org/10.1016/S00928674(00)81444-0)

Thibonnier M, Conarty DM, Preston JA, Plesnicher CL, Dweik RA \& Erzurum SC 1999 Human vascular endothelial cells express oxytocin receptors. Endocrinology 140 1301-1309. (https://doi.org/10.1210/ endo.140.3.6546)

Towbin H, Staehelin T \& Gordon J 1979 Electrophoretic transfer of proteins from polyacrylamide gels to nitrocellulose sheets: procedure and some applications. PNAS $\mathbf{7 6}$ 4350-4354. (https://doi.org/10.1073/ pnas.76.9.4350)

Virgo BB \& Bellward GD 1974 Serum progesterone levels in the pregnant and postpartum laboratory mouse. Endocrinology 95 1486-1490. (https://doi.org/10.1210/endo-95-5-1486)

Vonderhaar BK 1999 Prolactin involvement in breast cancer. EndocrineRelated Cancer 6 389-404. (https://doi.org/10.1677/erc.0.0060389)

Wagner KU, Krempler A, Triplett AA, Qi Y, George NM, Zhu J \& Rui H 2004 Impaired alveologenesis and maintenance of secretory mammary epithelial cells in Jak2 conditional knockout mice. Molecular and Cellular Biology 24 5510-5520. (https://doi.org/10.1128/ MCB.24.12.5510-5520.2004)

Yamaji D, Na R, Feuermann Y, Pechhold S, Chen W, Robinson GW \& Hennighausen L 2009 Development of mammary luminal progenitor cells is controlled by the transcription factor STAT5A. Genes and Development 23 2382-2387. (https://doi.org/10.1101/gad.1840109)

Received in final form 21 July 2018

Accepted 7 August 2018

Accepted Preprint published online 8 August 2018 (c) 2018 Society for Endocrinology Published by Bioscientifica Ltd. Printed in Great Britain 